\title{
A NEW INVENTORY OF THE ROYAL ARAGONESE LIBRARY OF NAPLES*
}

\author{
Santiago López-Ríos
}

for Pedro Cátedra

I n Ferrara on 4 July $15^{23}$, Isabella del Balzo, Queen of Naples, sold a sizable portion of what remained of the royal Aragonese library to the humanist and book collector, Celio Calcagnini. A record of this transaction has survived in a manuscript, now in Madrid, listing many of her possessions. ${ }^{1}$ This newly found inventory of $13^{2}$ books (hereafter $\mathrm{M}_{1}$ ) sheds light on the dispersal of one of the most important libraries of the Italian Renaissance.

Isabella del Balzo began her life of exile when the kingdom of Naples was invaded by the armies of France and Spain. This military occupation ended her husband Federico's brief rule (1496-1501) and forced the royal couple to move, with their rich library, first to the island of Ischia off the coast of Naples and soon after to France. There is evidence that they sold some of their books to Cardinal Georges d'Amboise and King Louis XII during their stay in France. ${ }^{2}$ In $1_{5} \mathrm{O} 7$, three years after Federico died, Isabella joined her sister, Antonia, at Gazzuolo, near Mantua. Seeking the protection of Alfonso d'Este, the next year she moved with her household to Ferrara, where she lived in the Palazzo di San Francesco until her death in $1533 .{ }^{3}$

Thanks to the studies of Giuseppe Mazzatinti, Tammaro De Marinis, José Alcina Franch and Genaro Toscano, ${ }^{4}$ much is already known about the royal Aragonese library. Nevertheless, a thorough assessment of the library's fate after its removal from Naples in $15^{\mathrm{O}} 1$ is still lacking. Until now, what little little information we had came from an inventory of $15^{27}$ listing 306 books (hereafter V), sent by Isabella to her son Ferdinand, Duke of Calabria, in Valencia. ${ }^{5}$ From $M_{1}$, however, we learn that, while in Ferrara, Isabella was in possession of more volumes than those eventually shipped to Spain. More importantly, this new inventory shows that in

* I am deeply indebted to Pedro Cátedra, who had intended to edit this inventory but most generously passed on this task to me and gave me very valuable advice and information. I would also like to express my gratitude to David Chambers, Ángel Gómez Moreno, Ottavio Di Camillo and Jill Kraye for their assistance. In addition, I want to thank Andrea Canova, Dominique de Courcelles, Guido Rebecchini, the staff of the Archivo Histórico Nacional (Madrid), the Archivio di Stato at Modena, the Archivio di Stato at Mantua, and the Biblioteca Comunale Ariostea (Ferrara).

Archive abbreviations used in this article:

ASMn, AG = Mantua, Archivio di Stato, Archivio Gonzaga

ASMod, ASE = Modena, Archivio di Stato, Archivio Segreto Estense

1. Madrid, Archivo Histórico Nacional, Sección de Códices MS $5_{52}^{6} \mathrm{~B}$, fols $17^{\mathrm{r}}-29^{\mathrm{r}}$.

2. G. Mazzatinti, La biblioteca dei re d'Aragona in Napoli, Rocca S. Casciano 1898 , pp. CXVII-CXXVII;
T. De Marinis, La biblioteca napoletana dei re d'Aragona, 4 vols, Milan 1947-52; Supplemento, 2 vols, Verona 1969, I, pp. 195-97, and II, pp. 201-04; G. Toscano, 'Rinascimento in Lombardia: i codici della biblioteca napoletana dei re d'Aragona acquistati da Georges d'Amboise', Croniques italiennes, xIX, 1992, pp. 77-87 $(78-80)$

3. On Isabella del Balzo's exile see S. López-Ríos, 'Pur ancor si dimostra esser regina: el exilio de Isabella del Balzo y la biblioteca aragonesa de Nápoles', El libro antiguo español, Ix, [forthcoming].

4. See the references cited above, n. 2; and J. Alcina Franch, La biblioteca de Alfonso $V$ de Aragón en Nápoles, 2 vols, Valencia 200o; La Biblioteca reale di Napoli al tempo della dinastia aragonese. La biblioteca real de Nápoles en tiempos de la dinastía aragonesa, exhib. cat. (Castel Nuovo, Naples 1998), ed. G. Toscano, Valencia 1998.

5. P. Cherchi and T. De Robertis, 'Un inventario della biblioteca aragonese', Italia medioevale e umanistica, XxxiII, 1990, pp. 109-347. 
the sixteenth century the library ended up not only in France and Spain, as was previously assumed, but also in Italy.

In this article I shall, firstly, analyse the inventory both as an historical document of intrinsic importance and in relation to other extant inventories of the Aragonese library. Secondly, I shall attempt to determine Isabella's attitude towards the library and also explore the use which contemporary men of letters made of the books in her collection. Thirdly, I shall place Celio Calcagnini's purchase of over 100 volumes from Isabella within the context of his literary interests and his passion for book collecting. Finally, in the Appendix, I shall provide an annotated edition of $\mathrm{M}_{1}$, together with an inventory of ten books which Isabella gave away in the same year, $15^{23}$ (hereafter M2).

\section{Analysis of the Inventory}

The inventory is found in a book of memoranda, dating from 1523 to 1533 , concerning Isabella's wardrobe and containing lists of her personal belongings. M 1 begins by indicating that Isabella ordered Federico del Tuffo, the keeper of her wardrobe (guardaroba), to sell a number of volumes to Celio Calcagnini for $15^{\circ}$ lire. Then follows a detailed description of the $13^{2}$ books which were sold. A statement at the end warns that the final three titles were missing at the time of preparing the inventory, but should nevertheless be given to Celio Calcagnini when they turned up. The reason for the sale is mentioned at the end of the document: most of the books were in poor condition due to water damage incurred when they were transported from Ischia to Marseilles and then from Marseilles to Ferrara. The inventory is dated at Ferrara on 4 July $15^{2} 3$ and is ratified by the queen's treasurer, Rinaldo Ottavanti. ${ }^{6}$

The compiler of the inventory was no doubt Federico del Tuffo, who was also in charge of the sale. He had been entrusted with the safekeeping of the Aragonese library since at least $15^{\mathrm{O}}$, when he accompanied the monarchs into exile in France. ${ }^{7}$ When the king died in $15^{0} 4$, Federico remained with the queen; and in 1508 he supervised the move of the royal possessions from Gazzuolo to Ferrara. ${ }^{8}$ He held the position of guardaroba menore at the time of the Calcagnini sale but was promoted to guardaroba maiore by $1527 .{ }^{9}$

Given Federico del Tuffo's many years of experience taking care of royal possessions, we might think that he himself was responsible for making the detailed list of the books. It seems, however, that he used a previous inventory of the Aragonese library, made sometime between $15^{\mathrm{O} 1}$ and $15^{\mathrm{O} 2}$, which is now lost but was apparently preserved in Ferrara at least until $1529 \cdot{ }^{10}$ In $\mathrm{M}_{1}$, after the description of 126 books there is a direct reference to a complete inventory

6. Rinaldo Ottavanti was a member of Isabella's household even before her arrival in Ferrara; see the letter from Isabella del Balzo to Isabella d'Este, dated 24 January 1508 at Gazzuolo: ASMn, AG, b. 803, c. 55 .

7 . The account book of the royal Neapolitan household for $15^{01}$ records a payment made on 10 August to Federico del Tuffo, who was entrusted with 'la portatura de XXI casse di libri de la libraria, da la marina de Hischia al castello de dicta terra': see Madrid, Archivo Histórico Nacional, Sección de Códices MS ${ }_{5}^{6}{ }_{1} \mathrm{~B}$, fol. $4^{\mathrm{r}}$. Federico del Tuffo's name appears several times in this account book: ibid., fols

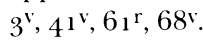

8. See the letter of Isabella del Balzo to Francesco Gonzaga dated 10 January 1508 . ASMn, AG, b. 803 , c. ว4.

9. Cherchi and De Robertis (as in n. 5), p. 135 . Long after Isabella's death, Federico del Tuffo was still associated with the Aragonese royal family. In $155^{\circ}$ we find him acting as a messenger for Ferdinand, Isabella del Balzo's son; see draft of a letter dated $155^{\circ}$ sent by Ercole II d'Este to Ferdinand: ASMod, ASE, Cancelleria, Minutario di lettere, b. 1512/31.

10. In a list of the possessions of the Aragonese dynasty of Naples, compiled in Ferrara on 10 May $15^{29}$, there is a reference to "lo inventario de tutti li 
made in Ischia: 'li sopra scripti centi vinti sei volumi de libri sono noctati a lo inventario grande fate in Isca' (fol. $28^{\mathrm{r}}$ ). The Ischia inventory is also mentioned in relation to the three manuscripts missing at the time of the sale: 'quale non se sonno trovati al presente' $\left(\right.$ fol. $\left.29^{r}\right) .{ }^{11}$ Moreover, we find the phrase 'quale non si trova in lo inventario' in the entries for the three books which are only sketchily described ( $\left.\mathrm{M}_{1} 13^{0-1} 3^{2}\right)$. It is regrettable that this original inventory has been lost, since it was clearly an unusually informative catalogue of a Renaissance Italian library.

The fact that $\mathrm{M}_{1}$ was copied from a carefully compiled inventory probably explains why the books to be sold were described in such detail. In general, the entries consist of an identification the work, an indication of the type of script and of whether the manuscript was written on parchment or paper, as well as the format. For illuminated manuscripts, the miniatures and illustrated borders on the first folio of the text are normally mentioned. As a rule, the entries end with a reference to the binding. Humanist terminology is often used to describe the different scripts: the majority are written in 'lettera moderna', that is, some form of gothic script; ${ }^{12}$ but a few are said to be in 'lettera antiqua', that is, a humanist script. ${ }^{13}$ The inventory also distinguishes between four types of 'bastarda' script ('bastarda', 'bastarda antiqua', 'bastarda corsiva' and 'bastarda moderna'). ${ }^{14}$ The entries in of $\mathrm{M}_{1}$ closely resemble those in $\mathrm{V}$, the inventory of books sent by Isabella del Balzo to her son Ferdinand. ${ }^{15}$ Given this similiarity, it seems safe to assume that $\mathrm{V}$ was also based on the lost Ischia inventory. ${ }^{16}$

The works listed in $\mathrm{M}_{1}$ are mainly religious, classical and humanist texts, together with several books of canon and civil law. All but two are manuscripts. For the most part, the texts are in Latin, although there are some in Italian, Spanish and French; and at least one (M1 62) may have been in Greek. Most of the religious writings appear to be grouped at the beginning (M 1 1-33), followed by works of classical authors and Italian humanists. The order of the books appears to be random, so that identical titles or works by the same author are not necessarily listed together (e.g., M1 14 and 109; 31 and 113).

Although much information in $\mathrm{M}_{1}$ is also found in other inventories of the Aragonese library, it does provide us with new data regarding the contents of the collection. From it we learn, for example, that Federico and Isabella owned copies of John of Salisbury's Policraticus $\left(\mathrm{M}_{1} 4^{2}\right)$, Hierocles of Alexandria's Commentarius in aurea Pythagoreorum carmina $\left(\mathrm{M}_{1} 4^{6}\right)$ and Claudian (M1 89). It also confirms that the library contained several works in Spanish. Considering the wide diffusion of Alfonso X's Partidas, ${ }^{17}$ it is not surprising to find a copy listed here

libri del Re che restarno in poter de Joanne Antonio de Costanzo in Ischia, receputo in Lione a 28 de ottubro ${ }_{15}$ o2': see G. March, 'Alcuni inventari di Casa d'Aragona compilati in Ferrara nel secolo XVI', Archivio storico per le province napoletane, LX, 1935, pp. 287-333 (321). Joanne Antonio di Costanzo was most likely a member of the royal household.

11. Fol. $29^{\text {r: }}$ "li predicti tre libri ... sono noctati al conto de li libri quali erano in poter del condan Joanne Antonio de Costanze, noctati a carte 36 et 37 et 38'; see M1 $127^{-29}$.

12. S. Rizzo, Il lessico filologico degli umanisti, Rome 1973, pp. $145^{-4} 4^{6}$.

13 . Ibid., pp. $117-22$.
14. On the 'bastarda' see B. Bischoff, Latin Paleography: Antiquity and the Middle Ages, Cambridge 1990, pp. $142-45$.

${ }_{15}$. V, however, is even more informative. The books are listed according to subject, and we are given the incipit and explicit of each manuscript; see Cherchi and De Robertis (as in n. 5 ), pp. $135^{-27} 8$.

16. The possibility that $\mathrm{V}$ derived from a lost catalogue of the roval Aragonese library was mentioned by Cherchi and De Robertis (as in n. 5), p. 129.

17. See A. García y García, 'La tradición manuscrita de las Siete Partidas', in España y Europa, un pasado jurídico común (actas del simposio, Murcia 1985), ed. A. Pérez Martín, Murcia 1986, pp. 655-99; and F. 
(M1 131). Less expected is Condestable of Portugal's Coplas del menosprecio e contempto de las cosas fermosas del mundo ( $\left.\mathrm{M}_{1} 125\right)$. In addition, the inventory allows us to establish the provenance of certain codices now extant in Italian libraries (M1 47 and 9o).

I have been able to identify five of the manuscripts listed in $\mathrm{M}_{1}$ with complete certainty (M $147,85,90,109,117)$. In addition, M 113 may refer to a codex preserved in the Biblioteca Comunale Ariostea, Ferrara, and $\mathrm{M}_{1} 92$ to one in the Biblioteca Ambrosiana, Milan. As we shall see, the books purchased by Celio Calcagnini were bequeathed, along with the rest of his library, to the Dominican friars of Ferrara. When their convent was dissolved at the end of the eighteenth century, its printed books and manuscripts were transferred to the public library of Ferrara, which at the time belonged to the university. ${ }^{18}$ This explains why four of the identified books listed in $\mathrm{M}_{1}$ are now in the Ariostea (M $147,85,90,109$ ). Not all the volumes from the Dominican convent, however, made their way to the public library; ${ }^{19}$ and it is possible that some of the books listed in $\mathrm{M}_{1}$ were among these. This seems to be the case, for instance, with the beautifully illustrated manuscript of the Divina Commedia ( 11117 ) owned by Antonio Testa of Ferrara at the beginning of the eighteenth century and then sold in 1702 to Girolamo Baruffaldi. Afterwards it remained in private hands and is now held in the Pierpont Morgan Library of New York (MS M.676; illustrated below, p. 237). The fate of this manuscript indicates that some of the Dominican convent's more valuable books may have been acquired before its dissolution.

\section{Isabella del Balzo and the Aragonese Library at Ferrara}

Queen Isabella (b. ${ }^{4} 6_{5}$ ), who never remarried after the death of her husband, spent the last years of her long exile in Ferrara, together with her children Isabella, Giulia, Alfonso and Cesare ${ }^{20}$ She arrived there in May ${ }_{1} 5^{\mathrm{o}}$, under the protection of her nephew, Alfonso I d'Este, who had succeeded his father, Ercole I, as Duke of Ferrara, Modena and Reggio, in ${ }_{15}{ }^{\circ}$. Alfonso was the son of Eleonora of Aragon, the sister of King Federico of Naples. Even though she received support from Alfonso and other rulers, Isabella continued to live in straightened circumstances for the rest of her days. She nevertheless strove to maintain her royal status; ${ }^{21}$ and it was this determination which was behind the repeated efforts she made to preserve her book collection, which was, after all, a symbol of courtly splendour.

Gómez Redondo and J. M. Lucía Megías, 'Las Siete Partidas', in Diccionario filológico de literatura medieval española: Textos y transmisión, ed. C. Alvar and J. M. Lucía Megías, Madrid 2002, pp. $15^{-27}$.

18. Ferrara, Università degli Studi, Archivio Generale e Storico, fasc. 1284 , Pro memoria dell'Università degli Studi presentata all'Amministrazione Centrale del Ferrarese... con la quale... si dimanda l'incorporazione alla Biblioteca dell'Università delli libri lasciati alli Domenicani da Celio Calcagnini..., Ferrara, 4 October 1796.

19. See G. Antonelli, Indice dei manoscritti della Civica Biblioteca di Ferrara. Parte prima, Ferrara 1884 , p. 8n. There is even evidence that manuscripts bearing the stamp of the University of Ferrara were removed from its library. This is what happened to London, British Library MS Burney 202, which contains Florus's epitome of Livy and a Roman calendar. On the first folio of this manuscript is the inscription: 'est conventus S. Dominici de Ferrara, ex dono domini Celii Calcagnini'. The stamp of the University of Ferrara is still visible on fol. $3^{\mathrm{r}}$. This manuscript was owned by Charles Burney (1757-1818), who bequeathed his books to the British Museum.

20. Her eldest son, the Duke of Calabria, was taken away from his parents in $15^{02}$, under the order of Ferdinand and Isabella, so that he could be raised in Spain. After many years as a pawn in Spanish foreign policy, he was finally named Viceroy of Valencia in ${ }_{1} 5^{2} 6$ by Charles V. See V. Castañeda, 'Don Fernando de Aragón, Duque de Calabria', Revista de archivos, bibliotecas y museos, xxv, 1911 , pp. 268-86.

21 . On Isabella's impoverishment and her attitude towards her royal status during her exile see LópezRíos (as in n. 3 ). 
By all accounts, Isabella was not a woman of academic learning. ${ }^{22}$ Nevertheless, she understood the cultural value of the royal library. We can gain some insight into her attitude towards such matters by examining the care she took to provide her youngest son, Cesare, with a humanist education. Cesare was born in $15^{\mathrm{O} 1},{ }^{23} \mathrm{a}$ few months before Isabella and her husband Federico were forced into exile. Having lost his father in $15^{04}$, he lived with his mother until his death in $15^{20} ;^{24}$ and it is she who would have been responsible for his education. Information about Cesare's schooling appears in his own correspondence, as well as in letters written by Isabella concerning his Greek teacher, Marco Antonio Antimaco. ${ }^{25}$ These letters show that between $15^{1} 7$ and 1519 , Antimaco, while at Ferrara, was trying to recover his rightful inheritance in Mantua and needed assistance from the Gonzagas. Isabella, who was very grateful to him for teaching Cesare Greek, wrote to the Gonzagas asking them to support the humanist's claims. Showering Antimaco with praise, she recommended him to Federico Gonzaga in 1519, 'as a man who was very learned in both Latin and Greek, and also a man of virtue, who has led an exemplary life', adding: 'for many months and years he taught Greek to the Infante Cesare, our most dear son, with great affection and efficiency, which is very pleasing to us and which leads us to wish and to attempt to secure every honour and advantage for him, so grateful are we for his services' ${ }^{26}$ The gratitude which she expresses towards Antimaco confirms that she was directly concerned with Cesare's education. Cesare himself sent a letter in his own hand, written in humanistic script, to Isabella d'Este, asking her to support Antimaco. His words, too, are full of gratitude towards his Greek teacher: 'I am especially indebted [to Antimaco] for having taught me Greek for two years, to my very great satisfaction.' ${ }^{27}$

In another letter, dated 10 July $15^{18}$, Cesare writes to Isabella d'Este, asking her to send him a work by the twelfth-century Byzantine author Eustathius:

22. Ibid.

23. See N. Giacomo, Cronica di Napoli, Naples 1845 , p. 239 .

24. A reference to the death of Cesare (10 October $15^{20}$ ) is found in Mario Equicola, Annali della città di Ferrara, Ferrara, Biblioteca Comunale Ariostea MS Cl. II, 355 , fol. $92^{\text {r }}$; however, Isabella's son is wrongly referred to as Carlo.

25. Marco Antonio Antimaco (c. 1473-c. 1551) was the son of the Mantuan scholar Matteo Antimaco. After studying in Sparta, Marco Antonio taught Greek in Mantua and Ferrara, where he held a position at the university between $15^{17}$ and 1545 . In addition to teaching, he wrote Greek and Latin poetry and translated various works from Greek into Latin, the best known of which is George Gemistos Pletho's Historia de gestis Graecorum post pugnam Mantineam. See A. Luzio and R. Renier, 'La cultura e le relazioni letterarie di Isabella d'Este Gonzaga. II. Le relazioni letterarie', Giornale storico della letteratura italiana, xxxIv, 1899 , pp. 1-97 (57-59); E. Faccioli, Mantova. Le lettere, II, Mantua 1962 , p. 413; and, for the most reliable information, Contemporaries of Erasmus: A Biographical Register of the Renaissance and Reformation, ed. P. G. Bietenholz and T. B. Deutscher, I, Toronto $19^{8} 5$, p. 62 , s.v. Antimaco, Marco Antonio.
26. Isabella del Balzo to Federico Gonzaga. Ferrara, 3 May 1519. ASMn, AG, b. 803, c. 208: 'per essere huomo doctissimo in ambe doe le lingue, dotato di virtù et vita exemplare ... con grande amore et diligentia ha demonstrato doctrina greca a lo infante Don Cesare, nostro figlio carissimo, più mese et anni, cosa che mi è sopra modo grata et me constrenge a desyderare et procurare omne suo honore et commodo, como quelle che li sente gratitudine del servicio'. She uses similar terms in other letters to Francesco Gonzaga (Ferrara, 11 May $15^{1} 7$. ASMn, AG, b. 803, c. 194) and Isabella d'Este (Ferrara, 4 May 1519. ASMn, AG, b. 803 c. 210 ).

27. Cesare d'Aragona to Isabella d'Este. Ferrara, 3 May [c. 1518]. ASMn, AG, b. 1197: 'In particular obligatione [towards Antimaco] per haverme lecto dui anni continui in greco con multa mia satisfactione' The esteem which Antimaco was held by the Aragonese royal family can also be seen in the letters of Cardinal Luigi of Aragon (c. $1473^{-1} 55^{1}$ ), who was at Ferrara in $15^{1} 7$ and again in $15^{18}$. He wrote first to Isabella d'Este (ASMn, AG, b. 1246, c. 277, 7 May ${ }_{15}^{17}$ ) and then to Tolomeo Spagnoli, Francesco Gonzaga's secretary (ibid., c. 495, 8 February 1518 ; and c. 497,20 February ${ }_{1}^{1} 5^{18}$ ) recommending Antimaco and extolling his virtues. 
Most Illustrious Lady, our very honoured sister. When messer Mario [Equicola] was here, I asked him to beg Your Ladyship to lend me the Greek Eustathius for some days, which I will take good care of. Not having yet received an answer from messer Mario, and desiring very much to see it, I beg Your Ladyship to give it to me for a few days; like the Hadrian [?], it will be safe. If you agree, you could send it with the bearer of this letter, Cola, the keeper of the Queen's wardrobe. I commend myself to Your Ladyship. Ferrara, 10 July $15^{18}$. The obedient brother of Your Ladyship, the Infante Cesare of Aragon. ${ }^{28}$

Cesare was probably interested in getting hold of a copy of Eustathius's commentary on the Iliad or the Odyssey, ${ }^{29}$ which he was presumably planning to read with Antimaco's assistance. This letter shows, in any case, that by 1518 he was already an accomplished student of Greek..$^{30}$

Just as Isabella, in spite of her financial difficulties, made every effort to give Cesare a good education, so too she took pains to transport the Aragonese royal library from France to Ferrara and to preserve it there for many years. Although there is no evidence that the library in Ferrara was the same lively centre of academic learning which it had been in fifteenthcentury Naples, it nevertheless seems reasonable to assume that the queen allowed scholars to use her books. We know for certain that her niece, Isabella d'Este, borrowed books from the library. On 17 March 1512 Luigi Toscano, a member of the queen's household, wrote to Isabella d'Este thanking her for returning a book from Mantua:

My Most Illustrious Lady: I humbly kiss your hands. Today I have received Your Most Illustrious Ladyship's letter with the book returned by messer Bernardino de Prosperi. I have reported this to Her Majesty the Queen, your mother, who commends herself to Your Reverence, saving it is not necessary to thank her for something she does willingly for Your Most Illustrious Ladyship, and that you may regard her as your mother. Ferrara, 16 May 1512. From Your Most Illustrious Lady's servant, Loysi Toscano. ${ }^{31}$

Unfortunately, Toscano does not reveal the title of the book which was being returned. Even so, this letter helps to explain Isabella d'Este's willingness to lend books to her cousin Cesare.

28. ASMn, AG, b. 1197: 'Illustrissima Domina, soror nostra honoratissima. Quando messer Mario [Equicola] fo qua, li commisi che pregasse la Illustrissima Signoria Vostra me volesse accomodare per alcun di de Eustatio greco, che li sera ben guardato. Et non havendome anco risposta da dicto messer Mario, et io tenendo molto desiderio vederlo, prego Vostra Illustrissima Signoria che me ne faccia gratia per alcun dì, che como Hadriano [?] li serà salvo, e piacendoli me lo porà mandare per lo presente Cola, guardarobba de la Signora Regina. Et a la Signoria Vostra me recomando. Ferrarie, X julii MDXVIII. [Autograph] De Vostra Illustrissima Signoria obediente fratello, lo Infante Don Cesare de Aragona.' The word marked with a question mark is not fully legible, but apparently refers to another book previously sent by Isabella d'Este to Cesare-possibly the biography of Hadrian in Scriptores Historiae Augustae. On the relationship between Mario Equicola and Isabella del Balzo see López-Ríos (as in n. 3).

29. Isabella d'Este did send the book to Cesare, as we can see from a letter by her dated $1_{5}$ July $1_{5} 18$, in which she asks him not to show it to too many people: 'essendo cosa rara, è da tener caro nè lassarlo vedere a molti, per non diminuirli la reputatione'; see Luzio and Renier (as in n. 25 ), pp. $24^{-25}$.

30. Cesare died two years later, at the age of 19. On his death, the musician Jacquet of Mantua composed the motet Ploremus omnes, in which Cesare is referred to as 'Maecenas', in his honour. See G. Nugent, 'The Jacquet Motets and Their Authors', Ph.D. diss., Princeton University 1973, p. 216 ; and W. M. McMurty, 'Ferdinand, Duke of Calabria and the Estensi: A Relationship Honored in Music', Sixteenth Century Journal, viII, 1977, pp. 17-30 (21).

31. ASMn, AG, b. 1244 , c. 1 o6: 'Illustrissima Signora Mia: Baso sue mano humelmente. Ho receputo questi dì la lettera de Vostra Signoria Illustrissima con el libro remandato per micer Bernardino de Prosperi. Ho satisfacto con la Maestà de la Signora Reyna, vostra madre, la quale se recomanda ala Reverentia Vostra et li dice non essere necessario regratiarla de cose che tanto volentieri fa per Vostra Signoria Illustrissima; che po desponere de Sua Maestà como de vera madre ... Ferrariae xvij martij 1 $5^{12}$. De Vostra Illustrissima Signora servitore, Loysi Toscano.' 
Also, it shows the personal interest which Isabella del Balzo took in her library: when the borrowed volume was returned to Ferrara, Toscano made a point of informing the queen.

The circumstances surrounding the sale of books to Celio Calcagnini provide further indications of the value which the royal library held in Isabella's eyes. True, she did sell off $13^{2}$ books; but it is significant that this happened only in $15^{2} 3$, that is, fifteen years after her arrival in Ferrara and nineteen years after she inherited the collection. There would doubtless have been many previous opportunities for her to sell the books. The financial constraints she was under at the time were clearly an important factor in her decision. According to the records of her wardrobe, in 1523 Isabella had to sell other belongings, mainly articles of clothing, valuable fabrics and tapestries. ${ }^{32}$ Interestingly, the amount of money she gained from the sale of these items was far greater than the proceeds from the books: she made only $15^{\mathrm{o}}$ lire from $13^{2}$ books; but four tapestries and some pieces of fabric fetched $5^{\text {o6 }}$ lire and 8 soldi. ${ }^{33}$ The sale of books none the less helped to alleviate her financial problems: in August of the same year she gave away ten further volumes, some of them in lieu of money for services received, ${ }^{34}$ for instance, from Cola di Gervasi, another of her guardaroba, who is also mentioned in V; ${ }^{35}$ Paulo Marmo, her physician; and Loyso de Riciis, her chaplain. ${ }^{36}$

We should keep in mind that the books which Isabella sold to Calcagnini were mostly water damaged. Moreover, they constituted only a portion of the library, the bulk of which she retained. In 1527 , five years after her son, the Duke of Calabria, was released from imprisonment in Spain, ${ }^{37}$ over 3 oo books were shipped from Ferrara to Valencia, where he had taken up residence. ${ }^{38}$ Apart from these volumes, Isabella's daughters took what we can assume was the remainder of the library to Valencia, when they joined their brother after her death in 1533. The Duke of Calabria died in $155^{\circ}$; and a posthumous inventory of his personal library, which he bequeathed to the monastery of San Miguel de los Reyes in Valencia, lists almost

32. See Madrid, Archivo Histórico Nacional, Sección de Códices MS $562 \mathrm{~B}$, esp. fols $42^{\mathrm{r}}-44^{\mathrm{v}}$.

33. Ibid, fol. $44^{\mathrm{r}}$. Although the document itself is not dated, it was no doubt written in $15^{23}$, since this is the date of those which precede and follow it in the manuscript.

34. See $\mathrm{M}_{2}$ in the Appendix below.

35. See Cherchi and De Robertis (as in n. 5), p. 135 . 36. In addition, Francesco Cantelmo received four books from her. He belonged to a noble family of Neapolitan origin, with links to that of Isabella. In a letter dated 21 June 1523 , addressed to Federico Gonzaga, Isabella refers to him as 'nostro parente' (ASMn, AG, b. 258). For the Cantelmo family in Ferrara see Alfonso Maresti, Teatro genealogico et istorico dell'antiche et illustri famiglie di Ferrara, Ferrara 168 1, II, pp. 48-57. See also Dizionario biografico degli italiani, Rome 1960- (hereafter $D B I$ ), xviII, p. 264, s.v. Cantelmo, Francesco.

37. The Duke of Calabria had been imprisoned in Spain in $15^{13}$ by King Ferdinand and was not released by Charles V until ${ }_{1} 5^{22}$. Isabella began to see Ferdinand's new situation in Spain as a way both to obtain some economic help and to protect her royal status. But, in 1523 , she was still uncertain about her son's future, as is evident from her letters to Isabella d'Este during that year, which show how anxious she was to receive news from the Duke of Calabria: ASMn, AG, b. 803 , c. 244 (Ferrara, 17 January [?] 1523); c. 246 (Ferrara, 3 February 1523), c. 259 (Ferrara, 21 June $\left.{ }_{1} 5^{2} 3\right)$. On 5 March $15^{23}$, Isabella d'Este wrote to Isabella del Balzo congratulating her on the release of her son (ASM, AG, b. 2998 , libro $4^{1}$, fol. $94^{\mathrm{r}}$; see also a letter dated 21 March 1523 , b. 2998, libro 42, fol. $12^{\mathrm{r}-\mathrm{v}}$ ). On 21 April 1523 , Isabella d'Este announced to Isabella del Balzo that her son Ferrante was going to Spain and that she could send with him letters for the Duke of Calabria (b. 2998 , libro 42 , fol. $5^{\mathrm{o}^{\mathrm{r}}}$; there is also another letter with similar contents, dated 3 May $15^{23}$, ibid., fol. $59^{v}$ ). A few months later, Isabella d'Este, having learned from her son that the Duke of Calabria was held in respect by Charles $\mathrm{V}$, passed on the news to Isabella del Balzo in a letter dated 18 September 1523 (ASMn, AG, b. 2998, libro 43, fol. $\left.{ }_{1} 8^{v}\right)$. On 28 September, she wrote again to Isabella del Balzo telling her that the Duke of Calabria 'di continuo era accarezato et honorato da Sua Maestà con libertà de entrare en camera sua ad ogni hora et tempo quando gli pareva' (ibid., fol. $26^{v}$ ). On the support which Isabella received from Charles $\mathrm{V}$ see López-Ríos (as in n. 3).

38. See Cherchi and De Robertis (as in n. 5 ). 
800 volumes, 100 of which are described as belonging to the infantas. ${ }^{39}$ Most of these books, presumably inherited by the duke after the death of his sisters ${ }^{40}$ must have come to them from their mother.

\section{Celio Calcagnini's Purchase of Books from the Aragonese Royal Library}

Celio Calcagnini (1479-1541) unquestionably recognised the intellectual value, as well as the material worth, of the books he purchased from Isabella. An avid bibliophile, he even asked to be buried at the entrance to the library of the Dominican convent in Ferrara, to which he bequeathed his own book collection. ${ }^{41}$

Born in Ferrara in 1479, Calcagnini, as a young man, combined a devotion to learning and classical languages with the pursuit of a military career. ${ }^{42}$ After years as a soldier, Calcagnini returned in 1506 to Ferrara, where he worked at the segreteria ducale. Between $15^{07}$ and $15^{\circ}$, he held a chair of Greek and Latin at the university. In $15^{10}$, he served as the chancellor to Cardinal Ippolito d'Este $\left(1479^{-1} 5^{20}\right) .^{43}$ Through this post, he became part of a literary circle, in which Ludovico Ariosto was the most prominent figure. Calcagnini's administrative and academic responsibilities did not prevent him from participating in various diplomatic missions in Italy, Hungary and Poland. Towards $15^{10}$, he was ordained priest and elected canon of the Cathedral of Ferrara, thus embarking on an ecclesiastical career which would provide him with a good income and earn him the rank of protonotario apostolico. ${ }^{44}$ In $15^{14}$, he was awarded a doctorate in canon and civil law from the University of Ferrara; and three years later, he was appointed official historian of the Este court.

A new stage in Calcagnini's life started in $15^{20}$, when his diplomatic career came to an end with the death of Cardinal Ippolito. He stayed in Ferrara, devoting his life to teaching and writing. A true humanist, he used to say that 'one can have too much of everything, except for learning'. ${ }^{45}$ His scholarly pursuits ranged from commenting on Pliny the Elder's Natural History to preparing a catalogue of Ferrarese medals. ${ }^{46} \mathrm{He}$ took part in the controversy over free will by writing a treatise, De libero animi motu $\left(15^{2} 5\right)$, in support of Erasmus's De libero arbitrio

39. Inventario de los libros de don Fernando de Aragón, duque de Calabria, Madrid 1875; repr. Valencia 1992, pp. 2, 5, 22-24, 27, 33, 34, 36-37, 39, 41-42, 44, $54-55,62-63,65,69,75-8$ o.

40. His sister Giulia died in Valencia in $154^{2}$ (see the letter in Spanish of the Duke of Calabria to Ercole II d'Este, informing him of Giulia's death; Valencia, 17 March 1542, ASMod, ASE, Cancelleria, Carteggio Principi Esteri, b. 1247/3). His other sister Isabella died in $155^{\circ}$, the same year as he did, but some months before (see the draft copy of a letter sent by Ercole II to the Duke of Calabria, expressing his sympathy at the death of Isabella: Ferrara, 22 May 1550. ASMod, ASE, Cancelleria, Minutario di lettere,

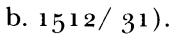

41. F. B. Borsetti, Historia almi Ferrariae Gymnasii ..., Ferrara 1735 , p. 199.

42. Although there is still no thorough study of the life and works of Celio Calcagnini, the essential facts can be found in: T. G. Calcagnini, Della vita e degli scritti di Monsignor Celio Calcagnini, protonotario apostolico,
Rome 1818; A. Lazari, Un enciclopedico del secolo XVI: Celio Calcagnini, Ferrara 1936 (offprint from vol. xxx of Atti e Memorie della Deputazione Ferrarese di Storia Patria); Q. Breen, 'Celio Calcagnini (1479-1541)', Church History, xxI, 1952, pp. 225-38; DBI, xvi, pp. 492-98, s.v. Calcagnini, Celio; C. Moreschini, 'Per una storia dell'umanesimo latino a Ferrara', in La rinascita del sapere: libri e maestri dello studio ferrarese, ed. P. Castelli, Venice 1991, pp. 168-88, esp. 168-73; eadem, 'Aspetti dell'attività letteraria di Celio Calcagnini', in 'In supreme dignitatis...' Per la storia dell'Università di Ferrara, I 39 II99I, ed. P. Castelli, Florence 1995, pp. $155^{-72 .}$

43. See $D B I$, XLIII, pp. $361-67$, s.v. Este, Ippolito d'.

44. See Lazari (as in n. 42), pp. 21-22.

45. See the dedicatory letter to Ercole II d'Este by the editor, Antonio Brasavola, in Celio Calcagnini, Opera aliquot, Basle ${ }_{1} 544$ : 'Omnium rerum esse satietatem, praeterquam discendi'.

46. See L. Tondo, 'Celio Calcagnini: l'uomo e l'umanista', in 'In supreme dignitatis...' (as in n. 42 ), pp. $173-84$. 
against Luther; in 153 os he was drawn into the polemic surrounding Henry VIII's divorce. ${ }^{47}$ He also wrote De imitatione (1532), in which he argued that Cicero should not be the only model for writing Latin. His anti-Ciceronianism was developed further in Disquisitiones aliquot in libros Officiorum Ciceronis (1536), a sustained attack on Cicero's style. Apart from these polemical tracts, Calcagnini wrote Latin poetry, orations and several theological treatises (De Trinitate, In sacramentum Eucharistiae), as well as carrying on a copious correspondence. ${ }^{48}$ Most of his works were published posthumously in Basle in 1544 , at the expense of Ercole II d'Este. ${ }^{49}$

Calcagnini probably came into contact with Isabella del Balzo several times before purchasing part of her book collection. In September 1508 , shortly after she arrived in Ferrara, he delivered a Latin oration at the memorial service held in Ferrara for her sister-inlaw, Beatrice of Aragon, who had died in Naples. ${ }^{50}$ It is unlikely that Isabella del Balzo would have missed this event. Moreover, Cardinal Ippolito d'Este, for whom Calcagnini worked from $15^{10}$ to 1520 , was her nephew. This position would have given Calcagnini the opportunity to strengthen his ties with the queen. ${ }^{51}$ And we know that a decade after the sale, Calcagnini delivered an oration on the wedding of Isabella's daughter Giulia to Giovan Giorgio of Monferrato. ${ }^{52}$

Although Calcagnini's interest in book collecting dates from well before $15^{23}$, as is evident from his correspondence, ${ }^{53}$ it is not surprising that this major purchase happened shortly after he had ended his diplomatic career, settled in Ferrara and devoted himself completely to his studies. The $15^{\circ}$ lire which he paid for the books seems a rather large sum for his limited budget, amounting to half of the yearly salary he received from the University of Ferrara for the academic year $1523-24 \cdot{ }^{54}$ But if we consider that he had other sources of income, ${ }^{55}$ the cost of acquiring manuscripts with a royal provenance does not seem exorbitant. As a

47. See A. Roncaglia, 'La questione matrimoniale di Enrico VIII e due umanisti italiani contemporanei', Giornale storico della letteratura italiana, cx, 1937, pp. 106-19.

48. For further information on Calcagnini's writings see Moreschini (as in n. 42 ), pp. $168-73$.

49. Calcagnini, Opera aliquot (as in n. 45 ).

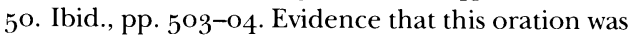
actually delivered in September ${ }_{15} 08$ can be found in Paolo da Lignano, Cronica Estense, ASMod, Biblioteca, MS 69, p. 434. Calcagnini's oration does not mention Isabella, since only the male members of the family are alluded to: 'Hinc celeberrimus Beatricis pater Ferrandus, hinc clarissimi fratres Alphonsus ac Federicus, ambo reges, ambo virtute ac fortuna memorabiles': Calcagnini, Opera aliquot (as in n. 45), p. $5^{\circ}$.

$5^{1}$. Several letters preserved in the ASMod show that Cardinal Ippolito was aware of Isabella's misfortunes and that the queen sought his help on a number of occasions. Of particular interest are the letters written by Isabella to Ippolito from France and Gazzuolo in 1507: see ASMod, ASE, Cancelleria, Carteggio Principi Esteri, b. $1247 / 3$.

$5^{2}$. See the letter by Geronimo Augusto to Isabella d'Este. Ferrara, 29 March 1533 . ASMn, AG, b. $125^{\circ}$.
This oration is not included in Calcagnini's Opera aliquot (as in n. 45). The letters of Isabella del Balzo to the Gonzagas which I have examined (ASMn, AG, b. 8o3) do not, however, mention the sale; nor does the correspondence of Calcagnini for that year printed in his Opera aliquot, pp. 108-o9, contain any reference.

53. On many occasions he explains how he had gained access to private libraries. In $15^{19}$, he wrote to Jakob Ziegler telling him about how he had read a Greek manuscript of Ptolemy in the royal Hungarian library: Opera aliquot (as in n. 45), p. 96. That same year, he wrote again to Ziegler, from Rome, boasting that Girolamo Aleandro, the papal librarian, was showing him every day the great treasures of the collection, ibid., p. 101: 'Is mihi quotidie ingentes thesauros ex bibliotheca palatina eruit'. For similar items in Calcagnini's letters see Moreschini (as in n. $4^{2}$ ), pp. $170-71$.

54. See Nuovi documenti relativi ai docenti dello studio di Ferrara nel sec. XVI, ed. A. Franceschini, Ferrara 197o, p. 20.

55 . We know that in $15^{19}$ he had to go to Rome to secure the large revenues he received from his ecclesiastical benefices; see Lazari (as in n. 42 ), p. 30 . Calcagnini must also have received compensation from 
bibliophile, he would obviously have been eager to possess 132 volumes from one of the most important fifteenth-century Italian libraries. The fact that he for the most part bought old manuscripts, many of them illuminated, and only two printed books speaks for itself. But Calcagnini was not merely a book collector. In $15^{23}$, at the age of forty-three, he was also an accomplished humanist, with a sound knowledge of Latin and Greek and a wide range of academic interests, reflected in his acquisition of books on many different subjects. As a priest, he would have wanted to own missals, psalters and works by the Church Fathers. As a scholar well versed in civil and canon law, it is understandable that he bought, for instance, the three parts of the Digest and Tancred of Bologna's Ordo iudicarius (M 1 95, 96, 99 and 10o). His strong humanistic inclinations account for that fact that most of the titles he purchased were works by classical authors or by other humanists. Nor is it is surprising, given his literary interests, that he wanted to acquire manuscripts with miniatures of famous Italian authors $\left(\mathrm{M}_{1}\right.$ $116,117)$.

If we compare $\mathrm{M}_{1}$ with $\mathrm{V}$, it becomes clear that Calcagnini did not always get the most valuable copies of the works in Isabella del Balzo's library. For example, she sold him an Appian manuscript $\left(M_{1} 66\right)$ but kept a more precious one with the arms of the Duke of Calabria (V, 155). Similarly, while Calcagnini bought a manuscript of Justinus ( $M_{1} 67$ ), Isabella held on to a finer codex, with the arms of Ippolita Sforza $\left(\mathrm{V},{ }_{15} 6\right)$. In addition, there are several duplicates in the list of the books purchased by Calcagnini ( $\mathrm{M}_{1} 7,8$ and 9; 27 and 28; $3^{1}$ and $113 ; 35$ and $4^{1 ;} 37$ and $38 ; 5^{0}$ and $5^{1} ; 5^{6,57}$ and $115 ; 83$ and 84 ). It is noteworthy, moreover, that Calcagnini bought works in Spanish (M $1120,125,131)$, which were less relevant to his studies than other volumes in the royal library. Although this might be explained by his sheer love of book collecting, it is unlikely that he had a free hand to select whatever volumes he wanted from the queen's collection.

His purchase of books from the Aragonese library was an investment which proved to be both financially sound and intellectually rewarding for him. Even if he was not able to choose all the works he would have liked, he definitely got some books which were very important to him and which were, in addition, real treasures of the royal collection. ${ }^{56} \mathrm{He}$ obtained, for example, an extremely valuable manuscript of Dionysius Periegetes's Cosmographia (M1 62), with elegant illustrations and rubrication in silver and gold. It appears to have been the only copy of this work in Isabella del Balzo's collection, since the title is not included in any other known inventory of the Aragonese library. Apart from the value of the manuscript itself, Dionysius's Cosmographia was a text which had interested Calcagnini for many years: in $15^{12}$ he had annotated a Latin translation of it printed in Ferrara by Giovanni Mazzocchi. ${ }^{57}$ Another of his important acquisitions was a manuscript of the Latin poems of the Ferrarese humanist Tito Vespasiano Strozzi ( $\mathrm{M}_{1}$ 9o). This codex, which is still extant, is as fine as the description suggests, with gold initials and illuminated margins (illustrated below, p. 231 ). ${ }^{58}$ Moreover, it

Cardinal Ippolito and the Duke of Ferrara for his services.

$5^{6}$. Calcagnini was considered an expert on manuscripts: in the same year that he bought the books from Queen Isabella he was asked to provide advice on a sale of books by a relative of one of his friends; see his letter to Camillo Cittadino (Ferrara, 26 September ${ }_{1523}$ ), in Opera aliquot (as in n. 45), p. 108.
57 . Dionysius Periegetes, De situ orbis, Ferrara 1512. It is conceivable that Calcagnini had previously been allowed to consult the manuscript in Queen Isabella's palace, just as he had gained access to the Hungarian royal library and the Vatican library (see n. 53 above). $5^{8}$. Ferrara, Biblioteca Comunale Ariostea MS Cl. I, 368. See Ml 90. 
is in excellent condition, which shows that not all the books listed in Ml were damaged. Finally, it was a volume which Calcagnini, with his love of Latin poetry, would surely have been very keen to possess. ${ }^{59}$ His high estimate of the books he bought from Isabella del Balzo is shown by the fact that he held on to the majority of them. A comparison of $\mathrm{M}_{1}$ with a posthumous inventory of Calcagnini's library indicates that over ninety per cent of Isabella's books remained in his possession at the time of his death. ${ }^{60}$

It seems, therefore, that the sale of these books benefited both parties. Isabella del Balzo obtained funds which helped to alleviate her impoverished condition and also allowed her to retain the larger part of the library. Celio Calcagnini was able to acquire a notable quantity of valuable manuscripts, many of them relevant to his humanist endeavours, at a very reasonable price. As for the royal Aragonese library, its break-up was without doubt a great loss. Yet even though it was no longer at the heart of an intellectual community, as it had been in Quattrocento Naples, we now know that the dispersed and fragmented collection continued to play a small, but nevertheless significant, role in the cultural and intellectual life of Italy in the following century.

\section{Universidad Complutense de Madrid}

The manuscript

\section{Appendix}

Madrid, Archivo Histórico Nacional, Sección de Códices MS $5_{52}^{6} \mathrm{~B}$ is written on paper in a humanist script by several different hands. The manuscript measures $35^{\circ} \times 118 \mathrm{~mm}$ and comprises $9^{2}$ folios grouped into six quires with the following collation: $1 \times 12(12) ; 1 \times 16(28) ; 2 \times 14\left(5^{6}\right) ; 1 \times 20(76)$ and $1 \times 16(92)$. There is contemporary foliation, with the numbering starting in the upper right-hand

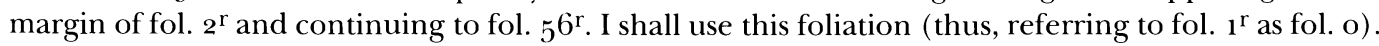
Folios $0,53^{\mathrm{v}}, 54^{\mathrm{r}}-55^{\mathrm{v}}, 84^{\mathrm{r}}, 84^{\mathrm{v}}$ and $9 \mathrm{o}^{\mathrm{v}}-9 \mathrm{1}^{\mathrm{v}}$ are blank. A watermark, consisting of an anchor within a circle with a six-pointed star superimposed, appears on many of the pages. This design suggests that the paper is of Italian origin. ${ }^{61}$ Although the parchment binding shows signs of deterioration, the manuscript itself is in good condition. The right-hand inside flap of the cover has a strip of leather attached. The words 'Reina $\mathrm{D}^{\mathrm{a}}$ Germana' written in blue pencil appear on the cover; below this, the stamp of the Archivo General of Valencia is still faintly visible. On the spine, a small label records the shelfmark $5^{62} \mathrm{~B}$, which also appears in blue pencil on the inside cover.

We can safely assume that the manuscript was sent from Ferrara to the Duke of Calabria in Valencia after the death of his mother in 1533 . When the duke died in $155^{\circ}$, it was passed on to the

59. Calcagnini's Latin poetry was published after his death by Giovan Battista Pigna in a volume containing Pigna's own Latin poems and those of Ariosto: Giovan Battista Pigna, Carminum lib[ri] quatuor ad Alphonsum Ferrariae Principem. His adiunximus Caelii Calcagnini Carm[inum] lib[ri] III. Ludovici Areosti Carm[inum] lib[ri] III, Venice ${ }^{1553}$. Some poems by Calcagnini had appeared before in Lilio Gregorio Giraldi's Dialogi duo de poetis nostrorum temporum, Florence 1551. Tito Vespasiano Strozzi's poems were not available in print until ${ }_{15} 30$ : see Strozzi poetae pater et filius, Paris 1530.

6o. Calcagnini's library inventory, dated 29 May $154^{1}$, is a list of over 1,100 books which passed, after the scholar's death, to the Dominican convent in
Ferrara. Although the descriptions of books in this inventory are very brief, usually only giving the title and the author of the work, it is clear that most of the titles of $M_{1}$ remained in Calcagnini's library. The items not found in Calcagnini's inventory are $M_{1} 11$, $33,36,42,120,122,126$ and 130-32. Also, many of the descriptions in the two inventories are very similar (e.g., M1 83: 'Juvenalis, de lettera longobarda'; Calcagnini inventory: 'Juvenalis antiquus longobardus'). For Calcagnini's inventory see ASMod, Archivio Privato Calcagnini, cassetta 95 , fasc. 72 .

61. See C. M. Briquet, Les Filigranes. Dictionnaire historique du marques du papier, I, Leipzig 1923, p. 4o. 


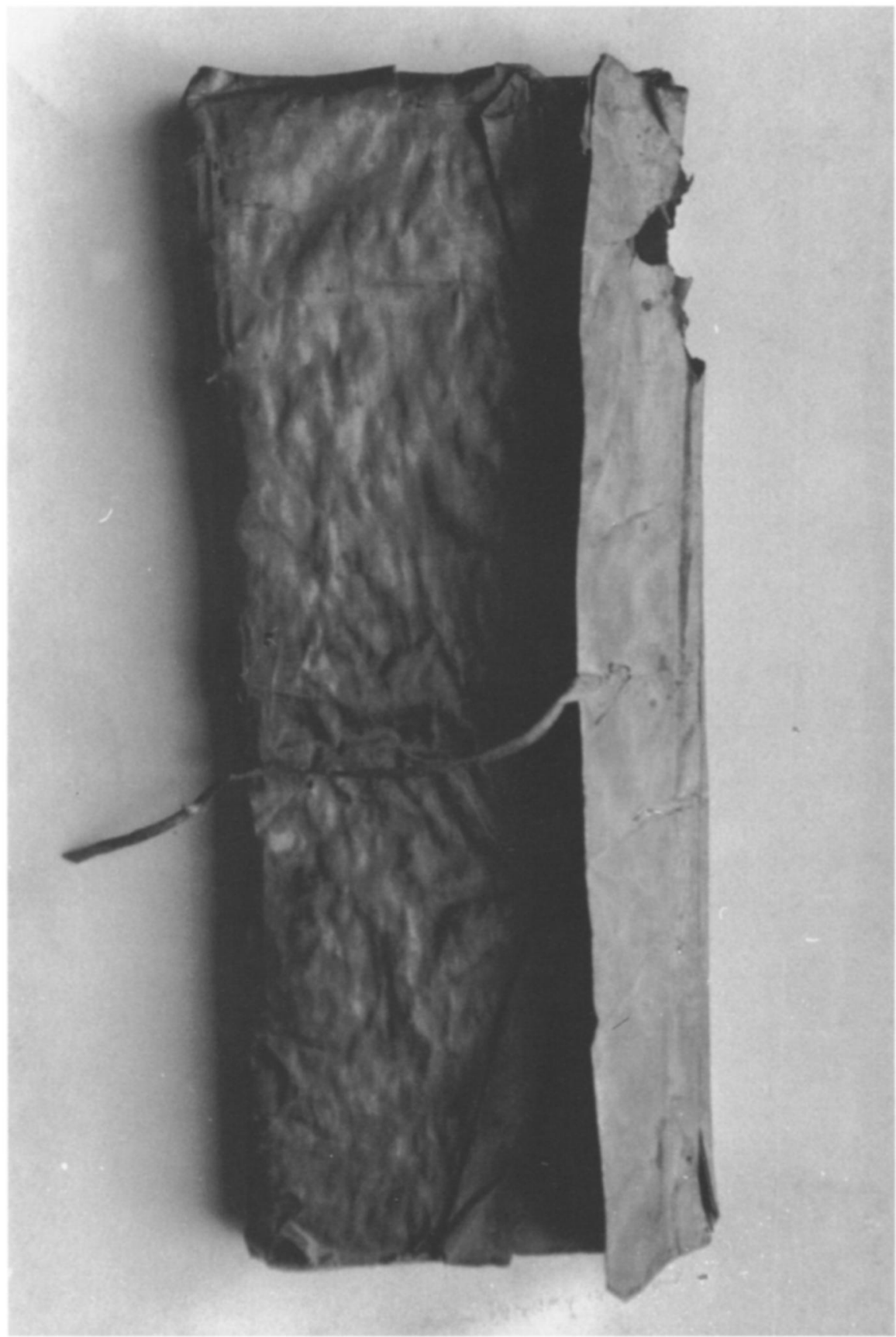

M1: Madrid, Archivo Histórico Nacional, Sección de Códices MS 562B, covering. (See also below, p. 220) (c) MINISTERIO DE EDUCACIÓN, CULTURA Y DEPORTE 
monastery of San Miguel de los Reyes (Valencia), which inherited his personal belongings and those of his first wife, Germana de Foix. ${ }^{62}$ After the monastery was dissolved in $1835,{ }^{63}$ the library-including this manuscript, as is shown by the stamp on its cover-passed to the Archivo General of Valencia. Finally, in 1897 , the manuscript, along with other documents and papers from the library of the duke of Calabria, were transferred to the Archivo Histórico Nacional, where they are still preserved. ${ }^{64}$

\section{Editorial principles}

In the transcription the following conventions have been adopted: when ' $u$ ' is used as a consonant, it has been transcribed as ' $v$ '; all abbreviations have been silently expanded; accents and punctuation have been introduced according to modern Italian practice; corrections to the text are indicated in footnotes; editorial additions to the text appear in square brackets; each entry in the inventories has been numbered.

The annotation includes the identification of the work and references to the same work in other inventories of the Aragonese library and Calcagnini's post mortem inventory. ${ }^{65}$ Doubtful identifications are marked with a question mark. When possible, I have also indicated the present location of the manuscript, with a brief description and bibliography. In some cases, I have also mentioned other extant manuscripts of the royal Aragonese library for comparative purposes.

\section{Abbreviations}

A Inventory of the books given by King Ferrante to Battista Pandolfini as a guarantee of the loan which he received to fight the Turks (19 January 1481). See De Marinis (as in n. 2), II, pp. 187-92.

B 'Index regalium codicum Alfonsi Regis ad Laurentium Medicem, ex Neapolitana eius bibliotheca transmissus'. Written by Fabio Vigili from Spoleto c. ${ }^{1} 5^{\mathrm{o}}-1$. 3 . Copy of an original inventory sent from Naples to Lorenzo de' Medici. See De Marinis (as in n. 2), II, pp. 193-200.

C Inventory of 138 manuscripts sold by Federico of Aragon to Cardinal Georges d'Amboise some time between ${ }_{1} 5^{02}$ and ${ }_{15}$ 4. See De Marinis (as in n. 2), II, pp. 201-04.

D Inventory of royal belongings, Ferrara 1529 . See March (as in n. 1o), pp. 292-333.

G Inventory of the books bequeathed by the Duke of Calabria on his death $\left({ }_{15} 5^{\circ}\right)$ to the monastery of San Miguel de los Reyes. See Inventario de los libros de Don Fernando de Aragón (as in n. 39). In this case, I have only taken into account those works which clearly belonged to the infantas, the Duke of Calabria's sisters, since these were probably books inherited from their mother and therefore of Neapolitan origin. We should not forget that although the Duke of Calabria's collection consisted, to a large extent, of books from the royal Aragonese library, he must have acquired many other volumes during his lifetime.

$\mathrm{V}$ Inventory of the books sent from Ferrara to Valencia by Isabella del Balzo to the Duke of Calabria in $15^{27}$. See Cherchi and De Robertis (as in n. 5), pp. $135^{-27} 8$.

62. This explains why the manuscript was for a long time incorrectly linked to Germana de Foix in the catalogue of manuscripts of the Archivo Histórico Nacional. The error was primarily the result of a rather hasty cataloguing process; but it is understandable given the manuscript's provenance. Many documents concerning Germana de Foix were preserved in the monastery of San Miguel de los Reyes, together with those of the Aragonese kings of Naples. Some of these documents are now in the Archivo Histórico Nacional in Madrid.
63. Diccionario de historia eclesiástica de España, III, Madrid 1973, p. $165^{2}$.

64. See Vicente Vignau, 'Inventario de los documentos y libros que han ingresado en el Archivo Histórico Nacional en el mes de la fecha [septiembre ${ }_{1897}$ ], procedentes del del Reino de Valencia', Revista de archivos, bibliotecas y museos, I, 1897 , pp. 465-73 (468).

65. Calcagnini's inventory (as in n. 6o) is divided into two parts, each with its own foliation: the inventory and the 'adiuto delo inventario'. 
Inventory $\mathrm{M}_{1}$

Madrid, Archivo Histórico Nacional, Sección de Códices MS $5^{62} \mathrm{~B}$, fols $17^{\mathrm{r}}-29^{\mathrm{r}}$

\section{Sua Reale Maestà}

Per ordine e servitio de quella, Federico del Tuffo, guardarroba menore de Vostra Maestà, ha venduto al reverendo micer Celio Calcagnino li subscripti volumi de libri per lo precio de lire cento cinquanta, quali libri erano in guardarroba de Vostra Maestà, in potere de Federico del Tufo supradicto, videlicet:

M 1 Missale, de lettera moderna, a colonelli, in carta peccorina, con lo calenderro in lo principio. Antiquo, senza ${ }^{66}$ minie. Coperto rosso, con quattro ciappe, con li cinti de sitin morato con frangioni.

MissaL

V, 6-10; Calcagnini invent. fol. $8^{\mathrm{r}}$ ('Missale').

M1 2 Psalterium golosato, de lettera antiqua, in forma bastarda. Coperto lionato, con quattro ciappe et cinti de setta rossa.

PSALTER

A, 68, 160, 164; B, 400; V, 17, 21-24; Calcagnini invent. fol. $3^{\prime}$ ('Psalterium grecum'), fol. $7^{\text {' }}$ ('Psalterius abbati Joachim cum rubriche'); Adiuto delo inventario Calcagnini, fol. $2^{\mathrm{V}}$ ('Psalterium'), ('Psalterium glosatum').

M1 3 Psalterium, in carta membrana, in forma bastarda, de lettera antiqua, glosato. In la prima facie è una B per prima lettera miniata et la margine de socto miniata con le arme ducale. Coperto lionato stampato, con quatro ciappe et cinti de velluto carmesino.

Psalter

See M1 2.

Mi 4 Catholicon, de lettera moderna, scripto a colonelli, in carta pergamena, in forma reale bolognese. In la prima faccie, dove comentia la opera, è uno D grande per prima lettera miniata, dentro de la quale è uno frate scribente; miniato intorno per la margine; et abasso uno campo azuro con uno scuto de oro quartiato; al uno quarto, l'aquila negra con la corona; et l'altro, la bissa azura con la corona. Coperto de corduana alionata, stampato con $\mathrm{qu}[\mathrm{a}]$ ttro fronteri a li cantoni de ciascuna taula et una rosa in mezo, con qu[a] ttro ciappe, con le coregie de corame.

Giovanni Balbi, Catholicon

This manuscript may be the one copied by Joan Marco Cinico in 1470 . See De Marinis (as in n. 2), 11, p. $25^{2}$.

B, 25; Calcagnini invent. fol. $6^{\mathrm{r}}$ ('Catholicon').

Mi 5 Joannis Apochalipsis et Actus apostolorum, de lettera moderna, scripto a collonelli, in carta pecorina, in forma reale. La prima faccie è per la antiquità $\left[f o l . I^{\prime \prime}\right]$ inperrotta et caduch le lettere, con uno quatro in principio dove è una A grande per prima lettera semelmente per dicta antiquità caduca. Coperto de corduana rossa stampato, con quattro ciappe, con le cinte de seti nigro con frangioni et fila de oro per lo mezo.

Book of Revelation and Acts of the Aposties 
A, 53 ('Beati Joannis apocolixis et Actus apostolorum'), $5^{8}$ ('Biblia'), 185 ('Biblia'), 189 ('Biblia'); B, 420 ('Apocalypsis'); C, 103 ('Biblie textus'). G, 12 ('Otra Biblia en cuero amarillo, figurada de plata. De las infantas'); Calcagnini invent. fol. $3^{\mathrm{r}}$ ('Testamentum novum'), fol. $8^{\mathrm{r}}$ ('Appochalipsis et actus appostolorum'). Several Bibles are mentioned in $\mathrm{V}, 1-4$. Number 5 of this inventory is a Greek New Testament.

M1 6 Evangelica Luce et Joannis, de lettera moderna, scripte a colonelli, in carta pergamena, in forma reale, con lo testo de lettera grossa et lo comento de lettera minore. In la prima carta manca la prima lettera maiuscula. Coperto de corduana lionata, con quattro ciappe, con li cinti de seti chermosi con frangioni et fili de oro per lo mezo.

The Gospels of St Luke AND ST John

Calcagnini invent. fol. $7^{\mathrm{v}}$ ('Evangelia Luce et Joannis cum glosa'). See above, M1 5 .

Mi 7 Hieronymi epistole, de lettera bastarda, in quarto de foglio reale. Al incontro de la prima faccie è uno quatro grande quanto dicta faccie, dentro del quale è la figura de San Hieronymo et a la mano dextra tene una ecclesia, a la senestra uno libro. Coperto russo stampato, con doe ciappe.

ST JeRome, Epistolae

A, 15 ('Epistolarum Hieronimi prima pars'), 26 ('Hieronimi secunda pars'), 114 ('Epistole Hieronimi, ad stampa'); B, 362 ('Hieronymi opera in diversis codicibus, videlicet epistolae'); C, 100 ('Epistole

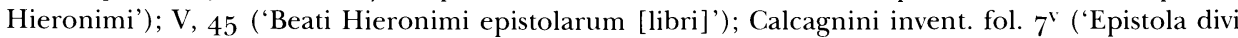
Hieronimi'), fol. 8r ('Epistola hieronimi').

M1 8 Hieronymi secunda pars Epistolarum, scripta a colonelli, in carta pergamena, in forma reale. Con la tavola in principio. La prima faccie miniata, senza arme. Coperto de corduana celostre, con quattro ciappe de ottone.

Sт JеRомe, Epistolae

See above, $M_{1} 7$.

M1 9 Hieronymi epistole, de lettera bastarda, scripto a colonelli, in forma reale. Con la tavola in principio. In la prima faccie, uno quattro con la figura de sancto Hieronymo innanzi lo crucifixo, miniate le margine con uno tundo abasso in bianco et in tucti li capituli sono quatretti con li primi capituli miniati. Coperto russo stampato, con quattro ciappe et cinti de siti negro. Lo quale libro è al numero deli [v]ulgari per causa ch'è [v]ulgare.

St Jerome, Epistolae. Perhaps in Italian.

See above, $M_{1} 7$.

M1 10 Hieronymi super Oxeam profetam et alia, de lettera antiqua, scripto a colonelli, in carta pergamena pecorina, in forma reale. La prima carta è scripta senza minie. De lettera per antiquità caduca et cossi dicta $\left[\begin{array}{lll}f o l & 1 & 8^{r}\end{array}\right]$ carta è cauduca et pertosata in più lochi. In la secunda faccie de dicta carta è uno quatro righe dentro de lettere maiuscule rosse et in la prima facie, dove comenza il prefacio, è uno I grandetto per prima lettera miniato. Coperto de corduana lionata stampato, con quattro ciappe de ottone, con li cinti de seti verde con frangioni.

Sт JеRомe, Super Oseam

B, $3_{67}$ ('Super Oseam prophetam'); V, 44 ('Hieronimus in duodecim profetis'); Calcagnini invent. fol. $6^{v}$ ('Hieronimus super Oxeam').

M1 11 Gregorii epistole, de lettera moderna, scripte a colonelli, in carta pecorina, in forma grande, che monstra antiquo assay. Et in la prima faccie de l'opera è una R per prima lettera grande 
de cinabrio. Coperto de corame lionato stampato, con quattro ciappe, con li cinti de velluto verde.

St Gregory the Great, Epistolae

M1 12 Gregorii dialagus, antiquo, in forma bastarda, de lettera antiqua. Coperto russo stampato, con quattro [ciappe] et cinti morati.

St Gregory the Great, Liber dialogorum

B, 373; Calcagnini invent. fol. 6' ('Dialogi Sancti Gregorij’), fol. $7^{x}$ ('Dialoghi papa gregori papa').

M1 13 Gregorii dialagus, de lettera moderna, scripto a colonelli, in carta pecorina, in volume picolo. In la prima faccie, dove comenza l'opera, è uno $Q$ maiusculo per prima lettera miniato simpliciter. Coperto de corduana rossa stampato, con quattro ciappe de ottone, con li cinti de seti nigro con frangioni et fili d'oro per lo mezo.

St Gregory the Great, Liber dialogorum

Ferrara, Biblioteca Comunale Ariostea MS Cl. II, 222 (‡). Fourteenth-century manuscript, in parchment, measuring $14^{1} \times 113 \mathrm{~mm}$ and written in gothic script, in two columns. See above, M1 12 .

M1 14 Augustini Rescriptum de Civitate Dei, de lettera bastarda corsiva, in membrana, de forma comune. Coperto russo stampato, con due ciappe et cinti celestri.

St Augustine, De civitate Dei

A, 124 ('Augustinus de civitate Dei, in stampa'), 255 ('Augustinus de civitate Dei, in stampa'); B, 355 (Augustini opera in diversis codicibus, videlicet De civitate Dei'), 4 oo ('Rescriptum super lib.

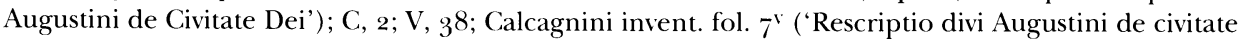
Dei').

Mi 15 Augustini libri XII super Genesim et alie, de lettera moderna a colonelli, con lo primo quinterno piu corto de li altri, antiquo. Coperto de russo stampato con quattro ciappe et cinti nigri.

St Augustine, Super Genesim

A, 134 ('Augustini super Genesim et alia opera'); Adiuto delo inventario Calcagnini, fol. 2" ('Augustini super Genesim').

M1 16 Augustini retrattationes, de lettera moderna, scripto a colonelli, con la tavola in principio. Et in la prima faccie del opera sono doe lettere maiuscule miniate che serveno per prima lettera. In parte studiato. Coperto de corduana russa stampato, con quattro ciappe de ottone, [fol. I $\left.8^{v}\right]$ con le cinti de seti carmesino, con frangioni.

St Augustine, Retractationes

V, 4o. Calcagnini invent. fol. 6' ('Policrates retrataciones divi Augustini').

M 17 Augustinus de sermone Domini in monte, de lettera corsiva, a colonelli, in forma de ottavo de foglio, senza minie. Coperto lionata stampato con doi ciappi.

St Augustine, De sermone Domini in monte (Matthew 5.1-3)

A, 132 ('Sermones. Augustini episcopi homelie'); B, 360 ('Augustini sermones'); G, 78 ('Homiliae et

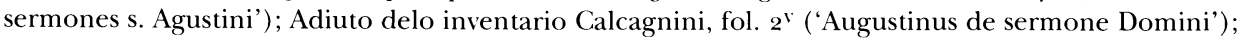
V, 39 ('Le omelie de Sancto Agustino').

M1 18 Ambrosius de excessu fratris et alia, in menbrana, de lettera antiqua, in forma bastarda. Coperto rosso stampato, con doi ciappi.

St Ambrose, De excessu fratris 
A, 66 ('Ambrosius de officiis, in pergameno, et de morte Satiri'); B, 374 ('Ambrosius de officiis'); V, 42 ('Sanctus Ambrosius de officiis et de morte Theodosii imperatoris et de morte Scotieri fratis sui'); Adiuto delo inventario Calcagnini, fol. 2' ('Ambrosius de excessu fratris').

M1 19 Thomas super Matheum, de lettera moderna, scripto a colonelli, con lo testo de lettera magiore et lo comento de lettera minore, in forma bastarda. In la prima faccie manca la prima lettera; senza minie. Coperto de corduana rosso, con quattro ciappi de ottoni, con cinti de seta negra.

Thomas Aquinas, Super Matthaeum

A, 21 ('Opera beati Thome, impergameno, de fide et alia opera'); C, 19 ('Sanctus Thomas super

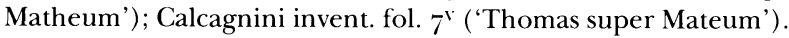

M1 20 Thome prima pars, de lettera moderna, scripto a colonelli, in forma reale bolognese. In la prima faccie de l'opera è uno quattro con uno $Q$ per prima lettera, dentro del quale è sancto Thomaso legente con altre figure audiente, con uno filetto de minie in torno. Coperto de corduana rossa, con quattro ciappe de ottone, con le cinti de velluto negro.

Thomas AQuinas, Summa theologiae $I^{a}$

A, 43 ('Theologia beati Thome compilatio'); B, $3^{82}$ ('Prima pars'); C, 12 ('Prima pars sancti Thome, couvert de velours vert, garny de quatre fermaus de loton, en façon de coquilles'); $\mathrm{V}, 55$; Calcagnini invent. fol. $7^{\mathrm{r}}$ ('Prima pars Sancti Thome').

Mi 21 Flores quatuor doctorum, de lettera moderna, a colonelli, in menbrana, in octavo de foglio, senza minie. Coperto lionata stampata con doi ciappi et cinti de seti verde.

Flores quattuor doctorum

B, 428 ('Flores Doctorum'); Adiuto delo inventario Calcagnini, fol. 2' ('Flores 4 doctores').

M1 22 Fratris Alexandri super Joannem, in menbrana, de lettera moderna, a colonelli, in forma reale. In la prima faccie è uno I per prima lettera. Coperto rosso stampato, con quattro ciappe, con le cinti de seti verde.

Alexander de Sancto Hel.pidio, Expositio Evangelii Beati Johannis

Paris, Bibliothèque Nationale MS Latin 640 is a manuscript of this work from the Aragonese library; but it cannot be the one described here, since we know that the Paris MS formed part of the section of the library dispersed in France. See De Marinis (as in n. 2), Suppl., I, pp. 16-17.

Calcagnini invent. fol. $7^{\mathrm{v}}$ ('Postila Alexandri super Joanem').

Mi 23 Benedictiones filiorum Jacob, de lettera bastarda de doi pene et de una mano, l'una più grossa et le righi piu larghe che le altre, trista lettera e vista, et multa antiqua, et alcune carte per dentro lo libro sono tagliate in margine de abasso et la ultima carta è meza caduca

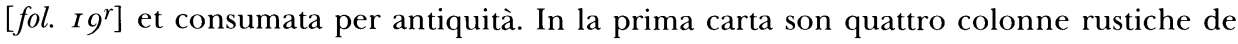
nigro, con quattro lettere ali capitelli et in mezo. Coperto de corduana russa stampato, con quattro ciappe de ottone et le coregie de cinto carmesino, con frangioni.

Probably a sermon on Genesis 49.10.

B, 422 ('Benedictiones filiorum Jacob'); Calcagnini invent. fol. $8^{\text {r }}$ ('Benedictiones filorum Jacob').

M1 24 Frater Egidius hordinis heremitarum de operibus sex dierum, de lettera moderna, a colonelli, in forma reale bolognese. In la prima faccie, dove comenza l'opera, è uno $\mathrm{C}$ grande per prima lettera miniato de verzin et azuro. Coperto de corduana russa stampato, con quattro ciappe de ottone, con li cinti de seti carmesino, con frangioni et filo de oro per lo mezo. 
GILES OF RoMe, Hexaemeron

Aiuto del inventario Calcagnini, fol. $3^{\mathrm{r}}$ ('Frater Egidius').

M1 25 Isidorus de victa Christi, de lettera antiqua, in quarto de foglio reale, con la tavola in principio. Et in la prima faccia de l'opera è uno quatro con uno $Q$ grande per prima lettera miniata. Coperto de nigro stampato, con due ciappi.

Probably a Pseudo-Isidorian work

Adiuto delo inventario Calcagnini, fol. 2" ('Isidorus de vita Christi').

M 26 Isidorii etimologiarum, de lettera moderna, a colonelli, in carta pergamena, in forma realle. In la prima faccia, dove comenza l'opera, è uno quatro con la figura de Isidoro legente, sotto del quale quadro è una rotta con dudici linee de russo, le ondice anno scripte et la duadecima è in bianco, con le margine in torno miniate con le arme ducale abasso. Coperto de corduana alionata, stampato de oro, con quattro ciappe de ottone, con le cinti de borcato celeste raso, con frangioni.

IsIdORE OF SEville, Etymologiae

Calcagnini invent. fol. $7^{\mathrm{v}}$ ('Isidori Ethimologiarum').

M 27 Legenda Sanctorum, de lettera moderna, scripto a colonelli, in carta pergamena, in forma reale. In la prima faccia, dove comenza l'opera, è uno A grande per prima lettera russa simplice. Coperto de corduana russa stampato, con quattro ciappe de ottone, con li cinti de seti verde, con frangioni et fili de oro per lo mezo.

JaCOBUS de Voragine, Legenda sanctorum

B, 445 ('Legenda sanctorum'); G, 210 ('Legenda sanctorum, cubierto de cuero leonado. De las infantas'); Calcagnini invent. fol. $8^{\mathrm{r}}$ ('Legenda sanctorum'); Adiuto delo inventario Calcagnini, fol. $3^{\mathrm{v}}$ ('Legenda sanctorum').

Mi 28 Legenda sanctorum, in menbrana, de lettera moder- $\left[f o l .19^{v}\right]$ na, a colonelli, in forma picola, senza minie. Coperto de rosso stampato de oro et cinti de veluto verde.

JaCOBUS de VoRAGine, Legenda sanctorum

See above, M1 27.

M1 29 Magister sententiarum, in menbrana, de lettera moderna, a colonelli, in forma picola. Con uno $\mathrm{O}$ in principio per prima lettera de rosso et azuro. Coperto rosso stampato, con quattro ciappe et cinti de seti negro.

Peter Lombard, Sententiae

B, 407 ('Magister sententiarum'); Adiuto delo inventario Calcagnini, fol. 2" ('Magister sententiarum') .

Mı 30 Speculum anime fratris Antonii Vitontini, de lettera corsiva miniata, a colonelli, in menbrana, a quarto de foglio. In la prima faccie è uno quadro con una $\mathrm{M}$ per prima lettera, dentro de la quale è la figura del dicto frate con una margine miniata. Coperto lionato stampato, senza ciappe.

Antonio of Bitonto, Speculum animae

Adiuto delo inventario Calcagnini, fol. $3^{\mathrm{v}}$ ('Speculum anime fratris Antonii').

M 31 Speculum fidei, in papiro, ad penna, de lettera cursiva. Coperto stampato, con quattro ciappe et cinti russi.

Robert of Cricklade, Speculum fidei 
Calcagnini invent. fol. 6” ('Speculum fidei et sermoni di fra Roberto'). See below, M1 113.

M1 32 Vita patrum, de lettera moderna, a colonelli, in menbrana, in forma comune, con la tavola in principio. Coperto lionato stampato, con quattro ciappe.

Vitae patrum

A, 155 ('Hieronimus de vitis Patrum'); B, 368 ('De vitis patrum'); Calcagnini invent. fol. 6 ('Vita patrum').

M1 33 Aristotilis de animalibus, de lettera moderna, scripto a colonelli, in parte gliosata, in carta pergamena, in forma reale. In la prima faccia, dove comenza l'opera, è uno quadro con una E per prima lettera, miniato in torno li dui colonelli d'un fileto. Coperto de corduana rossa stampato, con quattro ciappe de ottone, con li cinti de seta verde.

Aristotle, De animalibus

This manuscript may be the volume bound by Baldassare Scariglia in 1481 . See De Marinis (as in n. 2), II, p. 279 n. 638 .

B, 302 ('Aristot. de animalibus'); C, 82 ('Aristoteles de animalibus').

M1 34 Gorgias Platonis et alia, de lettera bastarda, in forma comune. In la prima faccia è uno B per prima lettera con le margine miniate. Coperto rosso con quattro ciappe et cinti de seti celestro.

Plato, Gorgias and other dialogues. Possibly Leonardo Bruni’s Latin translation.

B, 317 ('Platonis Gorgias et Apologia'); Adiuto delo inventario Calcagnini, fol. $2^{\mathrm{v}}$ ('Gorgias Platonis cum rubriche').

M1 35 Macrobius de sonno Sipioni, de lettera canzelaresca, in quarto de foglio reale, gliosato antiquo. Coperto lionato stampato, con dui ciappi.

Macrobius, Commentarium in Somnium Scipionis

A, 130 ('Macrobius, in pergameno, super sonno et diversa opera cum Apuleio'), 153, 198; B, 294; Calcagnini invent. fol. $4^{\mathrm{v}}$ ('Macrobius', 'Macrobius'), fol. $5^{\mathrm{r}}$ ('Macrobius cum rubriche'); Calcagnini adiuto delo inventario, fol. $2^{\mathrm{r}}$ ('Macrobius de somnio Scipionis'), fol. $4^{\mathrm{r}}$ ('Macrobius de somno Scipionis', 'In somnium scipionis').

M 136 Cicero de finibus bonorum et malorum, de lettera [fol. $2 o^{r}$ ] bastarda, in forma de quarto de foglio reale. In la prima faccie è una $\mathrm{H}$ per prima lettera, dentro de la quale è la figura de Tulio, miniate le margine con uno tondo abasso in bianco. Coperto rosso, con quattro ciappe et cinti de seta celeste.

Cicero, De finibus

For references to works by Cicero in other Aragonese inventories see V, 103-05, 225-26, 244-45.

M 37 Seneca de beneficiis, de lettera moderna, scripto a colonelli. In la prima faccie de l'opera è uno I per prima lettera a modo de uno pesse, miniata tucta a una margine. Coperto verde stampato, con quattro ciappe de seti carmesino.

SENECA, De beneficiis

B, 314 ('De beneficiis'); Calcagnini invent. fol. 6' ('Seneca de beneficiis'); Adiuto delo inventario Calcagnini, fol. $2^{\mathrm{v}}$ ('Seneca de beneficiis'). See also below, Mr 39.

M1 $3^{8}$ Seneca de beneficiis, de lettera moderna a colonelli, in carta menbrana, in forma comune, antiquo. Coperto lionato stampato, con quattro ciappe et rusicato lo spino de la coperta.

SENECA, De beneficiis 


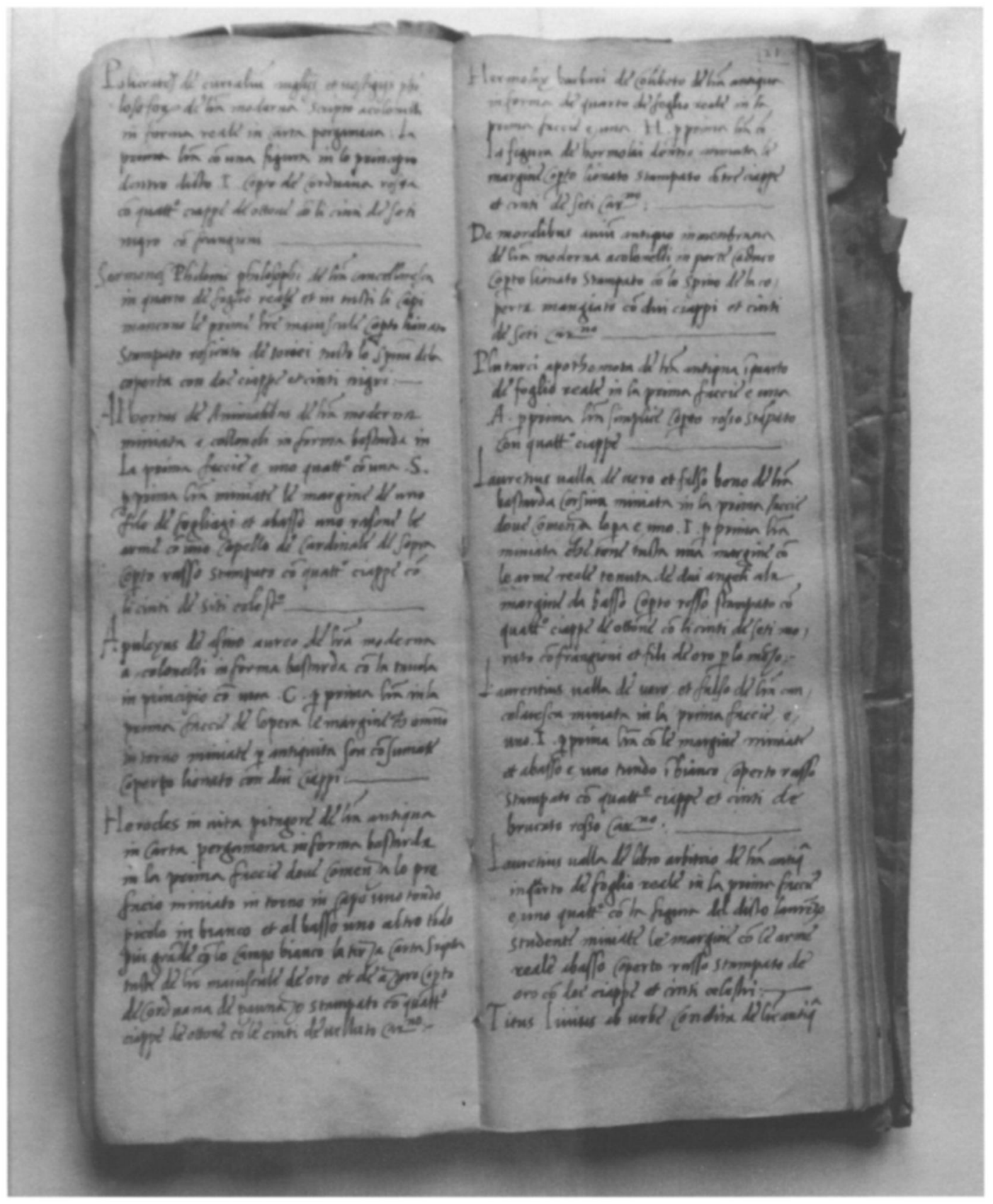

M1: Madrid, Archivo Histórico Nacional, Sección de Códices MS $5_{62}^{6} \mathrm{~B}$, fols $20^{\mathrm{v}-2} 1^{\mathrm{r}}\left(\mathrm{M}_{1} 4^{2}\right.$ to first line of M1 53 ) ๑ MINISTERIO DE EDUCACIÓN, CULTURA Y DEPORTE 
See above, M 37 and below, M 139.

M1 39 Senece conplura opera, in forma bastarda communa, con la tavola in principio. Et in la prima faccie de l'opera è una quadro con una $S$ per prima lettera miniata a le margine et abasso le armi ducale. Tucto lo volume è studiato e gliosato. Coperto de corduana verde stampato, con le ciappe, con li cinti de brucato raso carmesino.

SEneca, Opera

A, 54 ('Epistole Senece, in pergameno, cum beneficiis'), 118 ('Seneca diversa opera, in stampa recollecte'); B, 6o ('Epistolae Seneca'), 61 ('Commentarium super eisdem'), 299 ('Seneca de questionibus naturalibus'), 312 ('Moralia Seneca'), 314 ('Seneca de beneficiis'); V, 107 ('de consolatione, de tranquillitate animi, de vita animi, de brevitate vitae, de providentia, de remediis'), 108 ('tragedie'), 109 (idem), 110 (Opera omnia), 111 ('De questionibus nature et 13 altri trattati'); Calcagnini adiuto delo inventario, fol. $1^{\mathrm{v}}$ ('Senece tragedie'), fol. $2^{\mathrm{r}}$ ('Seneca'), fol. $2^{\mathrm{v}}$ ('Seneca aliquot opera').

M1 40 Aristotelis fisica et alia, de lettera moderna, in carta pergamena, in forma comune, studiato. In la prima faccie, doue comenza l'opera, et uno $Q$ per prima lettera, dentro del quale è la figura de Aristotile et due altre figure miniate. Coperto de corduana alionato, con sinque fronteri de ottone, con le cinti de velluto negro.

Aristotle, Physica and other works

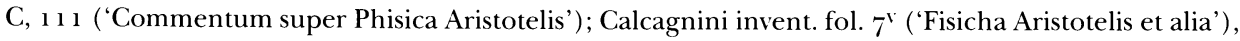
fol. $10^{\mathrm{r}}$ ('Fisicha Aristotelis cum rubriche Alberti Magni').

M 14 Macrobius de somno Sipionis, antiquo de più, lettere bastarda et antiqua. In la prima faccie è uno I per prima lettera, le due margine con uno tondo abasso in bianco. In forma de quarto reale strecto a la antiqua. Coperto verde stampato con una ciappa et cinto russo, abrusato una tavola da punta.

Macrobius, Commentarium in Somnium Scipionis

See above, M 135 .

M $4^{2}$ [fol. $2 O^{v}$ ]Policrates de curialium nugliis et vestigiis philosoforum, de lettera moderna, scripto a colonelli, in forma reale, in carta pergamena. La prima lettera con una figura in lo principio dentro dicto I. Coperto de corduana rossa, con quattro ciappe de ottone, con li cinti de seti nigro, con frangioni.

John of SAlisbury, Policraticus

M1 43 Sermones Philoni philosophi, de lettera cancellaresca, in quarto de foglio reale. Et in tucti li capi mancano le prime lettere maiuscule. Coperto lionato stampato, rosicato de soriei iusto lo spinno de la coperta, con doe ciappe et cinti nigri.

Philo, Sermones

Adiuto delo inventario Calcagnini, fol. 2' ('Philonis judei sermones').

M1 44 Albertus de animalibus, de lettera moderna miniata, a colloneli, in forma bastarda. In la prima faccie è uno quattro con una $S$ per prima lettera, miniate le margine de uno filo de fogliagi et abasso uno rasone le arme con uno capello de cardenale de sopra. Coperto russo stampato, con quattro ciappe, con li cinti de siti celesto.

Albert the Great, De animalibus

B, 289; Calcagnini invent. fol. 8r ('Albertus de animalibus').

M 45 Apuleyus de asino aureo, de lettera moderna, a colonelli, in forma bastarda, con la tavola in principio. Con una C per prima lettera in la prima faccie de l'opera, le margine che anno 
in torno miniate per antiquità son consumate. Coperto lionato con dui ciappi.

Apuleius, De asino aureo

B, 179 ('Apuleius de asino aureo'); Calcagnini invent. fol. $7^{v}$ ('Apuleius de asino aureo'), fol. $9^{\mathrm{v}}$ ('Apuleius de asino aureo cum rubriche'), Adiuto delo inventario Calcagnini, fol. 1 ('Apuleius').

Mi 46 Herocles in vita Pitagore, de lettera antiqua, in carta pergamena, in forma bastarda. In la prima faccie, dove comenza lo prefacio, miniato in torno in capo uno tondo picolo in bianco et al basso uno altro tondo più grande con lo campo bianco; la terza carta scripta tucte de lettere maiuscule de oro et de azuro. Coperto de corduana de paunazo stampato, con quattro ciappe de ottone, con le cinti de veluto carmesino.

Hierocles of Alexandria, Commentarius in aurea Pythagoreorum carmina

Adiuto delo inventario Calcagnini, fol. $2^{v}$ ('Hierocles in dictis pith.')

Mi $47\left[\right.$ fol. $2 I^{r}$ ] Hermolay Barbari de colibeto, de lettera antiqua, in forma de quarto de foglio reale. In la prima faccie è una $\mathrm{H}$ per prima lettera con la figura de Hormolai dentro, miniata le margine. Coperto lionato stampato, con tre ciappe et cinti de seti carmesino.

Ermolao Barbaro, De coelibatu

Ferrara, Biblioteca Comunale Ariostea MS Cl. II, 9 (De Marinis, as in n. 2, II, p. 181 ; Ermolao Barbaro, De coelibatu. De officio legati, ed. V. Branca, Florence 1969, pp. 8-11). Fifteenth-century manuscript, measuring $237 \times 157 \mathrm{~mm}$ and written in humanist script. The folio which contained a miniature of Barbaro has been removed. On the first folio is written: 'Est conventus sancti Dominici de Ferrarie ex dono domini Celio Calcagnini.' Explicit (fol. $124^{\text {') }}$ : 'Antonius Sinibaldus Florentinus, Ferdinandi Regis Scriba Neapoli hoc opus transcripsit. Anno Domini MCCCCLXXIII, ultimo d. maii'. The binding is original. This is the only known manuscript of Ermolao Barbaro's De coelibatu.

Calcagnini invent. fol. $6^{\mathrm{r}}$ ('Ermolaus barbarus de colibatu').

Mi $4^{8}$ De moralibus avium, antiquo, in menbrana, de lettera moderna a colonelli, in parte caduco. Coperto lionato stampato, con lo spino de la coperta mangiato, con dui ciappi et cinti de seti carmesino.

Hugh of Saint Victor, De bestiis et aliis rebus (book I) (?)

Adiuto delo inventario Calcagnini, fol. 2"' ('De moralibus avium').

M 49 Plutarci apothemota, de lettera antiqua, in quarto de foglio reale. In la prima faccie è una A per prima lettera simplice. Coperto rosso stampato, con quattro ciappe.

Plutarch, Apophthegmata. Probably Francesco Filelfo's Latin translation.

A, 86 ('Plutarcus grecus, diversa opera, in papiro'); B, 124 ('Apophthegmata Plutarchi'); Calcagnini invent. fol. $4^{\mathrm{r}}$ ('Plutarcus'); Adiuto delo inventario Calcagnini, fol. $2^{\mathrm{v}}$ ('Apophthegmata Plutarchi').

M1 $5^{\mathrm{O}}$ Lauretius Valla de vero et falso bono, de lettera bastarda corsiva miniata. In la prima faccie, dove comenza l'opera, è uno I per prima lettera miniata che tene tucta una margine, con le arme reale tenuta de dui angeli a la margine da basso. Coperto rosso stampato, con quattro ciappe de ottone, con li cinti de seti morato, con frangioni et fili d'oro per lo mezo.

LoREnzo Valla, De vero et falso bono

Calcagnini invent. fol. $8^{\mathrm{r}}$ ('Laurentius valla de vero et falso'); Adiuto delo inventario Calcagnini, fol. $2^{\mathrm{v}}$ ('Laurentius Valla de vero et falso'). On the presence of works by Valla in the Aragonese library see below, Mi 91 .

M $5^{1}$ Laurentius Valla de vero et falso, de lettera cancelaresca miniata. In la prima faccie è uno I per prima lettera, con le margine miniate et abasso è uno tundo in bianco. Coperto rasso stampato, con quattro ciappe et cinti de brucato rosso carmesino. 
Lorenzo Valla, De vero et falso bono

Calcagnini invent. fol. $8^{\mathrm{r}}$ ('Laurentius valla de vero et falso'); Adiuto delo inventario Calcagnini, fol. $2^{\mathrm{v}}$ ('Laurentius Valla de vero et falso'). On the presence of works by Valla in the Aragonese library see below, Mi 91 .

M1 52 Lauretius Valla de libro arbitrio, de lettera antiqua, in quarto de foglio reale. In la prima faccie è uno quattro con la figura del dicto Laurenzo studente, miniate le margine con le arme reale abasso. Coperto rasso stampato de oro, con doi ciappe et cinti celestri.

Lorenzo Valla, De libero arbitrio

Calcagnini adiuto delo inventario, fol. $2^{\mathrm{r}}$ ('Laurentius Valla de libero arbitrio cum rubriche'). On the presence of works by Valla in the Aragonese library see below, M 191 .

M1 53 Titus Livius ab urbe condita, de lettera antiqua, $\left[f o l .2 I^{v}\right]$ in forma reale, in carta pergamena. $\mathrm{Al}$ incontro de la prima carta de l'opera è uno quadro miniato in torno; et dentro de dicto quadro è scripto de lettere grande de oro lo titulo del libro; et in la prima faccie, dove comenza l'opera, è uno quadro con una F per prima lettera, dentro del quale è uno armato a cavallo, miniata tucta la margine in torno ad tronconi con teste antique et altri animali, con uno scuto abasso de oro miniato, con una aquila negra dentro. Coperto russo stampato de oro, con quattro ciappe de ottone, con cinti de brocato rosso carmesino.

Livy, Ab urbe condita

A, 17 ('Decades tres Livii'), 23 ('Quarta deca Livii'), 31 ('Quinta deca Livii'), 140 ('Livius de secundo bello Punico'); B, 142 ('Livius ab urbe condita; de secundo bello punico; et de bello macedonico'); C, $4^{1}$ ('Titi Livii de secundo Punico'), $4^{2}$ ('Titi Livii ab urbe condita'); V, ${ }_{1} 5^{0}-5^{2}$. Calcagnini invent. fol. $6^{\mathrm{v}}$ ('Titus Livius paduanus', 'Titus Livius'), fol. $13^{\mathrm{r}}$ ('Titus Livius'), Calcagnini adiuto delo inventario fol. $2^{\mathrm{r}}$ ('Decade di Tito Livio volgari', 'Titii Livii Decades'), fol. $7^{\mathrm{r}}$ ('Livius'). See also below, M 154 and M1 129 .

M 54 Titus Livius, de lettera bastarda, scripto a colonelli, in carta pergamena, in forma reale. In la prima facie, dove comenza l'opera, è uno quatro con lo campo de oro azuro et russo ad schiaachetti con Romulo et Remulo dentro dicto campo armati ad cavallo con Roma da sopra; et in la margine de sopra è uno scuto de azuro con due spate dentro in croce, con uno cappello de cardinale de sopra. In parte dicto volume è studiato. Coperto de corduana verde stampato, con quattro ciappe de otone, con li cinti de seti carmesino, con frangioni.

Livy, Ab urbe condita

See above, M 153 .

M 55 Mauritii distintiones, de lettera moderna, in carta pergamena, de forma bastarda, scripto a colonelli, in parte gliosato et studiato in monstra antiqua. In la prima faccie è uno $\mathrm{C}$ maiuscule per prima lettera et per antiquita dicte faccie è caduca. Coperto de corduana rossa, con quattro ciappe, con li cinti de seti celestre, con frangioni et fili de oro per lo mezo.

MaUritius Hibernicus, Summa distinctionum

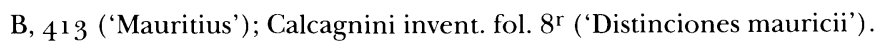

M 56 Valerius Maximus con gliosis [sic], de lettera moderna, [fol. $\left.22^{r}\right]$ scripto a colonelli, in carta pecorina, in forma grande. In la prima facia, dove comenza la opera, è uno quadro dentro del quale è uno inperator a cavallo in campo d'oro, e una cità in la parte denanci in dicto quadro, sotto de lo quale è uno $\mathrm{V}$ miniato per prima lettera. Coperto de paunazo stampato, senza ciappe.

VAlerius MaXimus, Factorum ac dictorum memorabilium libri IX

A, 81 ('Valerius Maximus, in stampa'), $127 ;$ B, $127 ; \mathrm{V}, 15^{8-}{ }_{59}$; Calcagnini invent. fol. $1 \mathrm{O}^{\mathrm{r}}$ ('Valerius 
Maximus'), fol. 13 $3^{\mathrm{v}}$ ('Valerio Maximo'); Adiuto delo inventario Calcagnini, fol. $2^{\mathrm{v}}$ ('Valerius

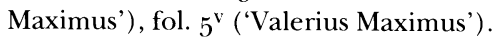

M1 57 Valerius Maximus, de lettera moderna, a colonelli, in forma comune, in menbrana. Coperto rosso stampato, con quattro ciappe et cinti nigri.

Valerius MaXimus, Factorum ac dictorum memorabilium libri IX

See above, $M_{1} 5^{6 .}$

M1 $5^{8}$ Salustius, de lettera bastarda moderna, in ottavo de foglio reale. Coperto lionato con doi ciappi et cinti rossi.

SAllust. It is not possible to determine whether this manuscript contained the Bellum Catilinae, the Bellum Jugurthinum or both.

A, 85 ('Salustius, in pergameno'); B, 143 ('Salustius'); V, 16o (Bellum Catilinae and Bellum Jugurthinum); Adiuto delo inventario Calcagnini, fol. $2^{\mathrm{r}}$ ('Salustius cum rubriche').

M1 59 Quintus Curcius, de lettera cancelaresca, in carta pergamena, de forma bastarda. In la prima faccie è uno I per prima lettera miniata longa quanto è la scriptura de dicta faccie. Coperto verde stampato, con quattro ciappe de ottone, con li cinti de seti carmesino.

Quintus Curtius, Historia Alexandri

A, 3, 42, 154; B, 144; V, 271 ('Quinto Curcio volgare'); Calcagnini invent. fol. $7^{\mathrm{v}}$ ('Quintus Curtius'); Adiuto delo inventario Calcagnini, fol. $2^{v}$ ('Quintus Curtius'), fol. $3^{v}$ ('Quintus Curtius'), fol. $5^{\mathrm{r}}$ ('Quintus Curtius'), fol. 5' ('Quintus Curtius').

M1 6o Quintus Curcius, de lettera bastarda miniata, in menbrana. In la prima faccie è uno I per prima lettera miniata et uno tondo abasso in bianco. Coperto rosso, con quattro ciappi di seti zallo.

Quintus Curtius, Historia Alexandri

See above, M1 59 .

Mı 61 Quintus Curcius, de lettera formata, in carta pergamena, in forma bastarda. In la prima faccia miniata in torno con uno scuto abasso de oro con l'aquila negra dentro incoronata. In forma bastarda, stampato, con tre ciappe et cinti de seti celestri.

Quintus Curtius, Historia Alexandri

See above, M1 59 .

M1 62 Dionisius cosmografus in versi et in prosa, de lettera cancelaresca, in carta pergamena, in forma picola, in lo principio ha doe $\left[f o l .22^{v}\right]$ carte rosse scripte con lettere maiuscule de oro et ad una delle faccie de la IIa carta è un quatro con lettere de oro et de argento et de sopra dicto quadro lettere grechi de argento, apresso le dicte due carte sequita una carta bianca con uno tondo, dentro del quale è disignato el mundo; et in la prima faccie, dove comenza la opera, ce sonno altri desegni; et al campo de sotto in la margine è uno tondo uno scuto paunazo con una sbara de argento. Coperto verde stampato, con dui ciappi.

Dionysius Periegetes, Cosmographia seu de situ orbis

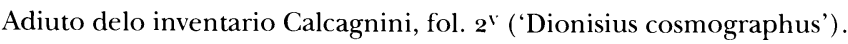

Mi 63 Josephus de vetustate judeorum, de lettera antiqua, in quarto de foglio reale. In la prima faccie è uno $\mathrm{S}$ per prima lettera miniata con le tre margine in torno abasso e uno scuto in bianco. Coperto rosso con quatro ciappe et cinti de seti carmesino.

Flavius Josephus, Antiquitates Judaicae 
A, 113 ('Josophi historie, in pergameno'); B, 163 ('Josephus Antiquitatum'); Adiuto delo inventario Calcagnini, fol. $2^{\mathrm{v}}$ ('Josephus de antiquitate judeorum'), fol. $7^{\mathrm{r}}$ ('Josephus').

Mi 64 Eutropius antiquitatum, in forma de quarto de foglio reale, de lettera bastarda antiqua. Coperto lionato stampato, con quattro ciappe et cinti de veluto nigro et seti russo.

EUTROPIUs, Breviarium ab urbe condita

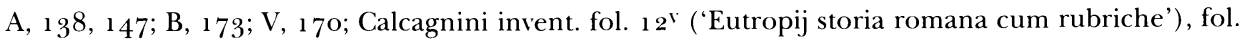
$13^{\mathrm{r}}$ ('Eutropii istoria romana cum rubriche'); Adiuto delo inventario Calcagnini, fol. $3^{\mathrm{v}}$ ('Eutropius historicus').

M 65 Egesippius de bello judaico, de lettera moderna, in octavo de foglio reale. Alle incontro de la prima faccie è uno $Q$ per prima lettera, dentro del quale è la testa de Jesippo, miniate le margine con le arme ducale abasso. Coperto verde con due ciappe et cinti de brocato celestre.

Pseudo-Hegesippus, De bello Judaico

Calcagnini adiuto delo inventario, fol. $2^{\text {r }}$ ('Eigesippus de bello judaico').

M 66 Appianus Alexandrinus de bellis sivilibus, de lettera bastarda de mala sorte interzate, in carta pergamena et banbacini, in foglio comune. In la prima faccie, dove comenza [ $\left.\mathrm{fol} .23^{r}\right]$ l'opera, manca la prima lettera maiuscula, dove è lassato uno quadreto in bianco. Coperto de corduana alionato, con quattro ciappi de ottone, de seti negro con frangioni.

APPIAN, Historia romana (books 13-17)

B, 153 ('Appianus Alexandrinus'); V, 155 ('Appiano Alexandrino historiografo'); Adiuto delo inventario Calcagnini, fol. $3^{\mathrm{v}}$ ('Appianus Alexandrinus'), fol. $5^{\mathrm{r}}$ ('Appianus Alexandrinus de bellis civilibus').

M 67 Justini epithoma, de lettera bastarda, in quarto de foglio, in menbrana. In la prima faccia è uno $\mathrm{G}$ per prima lettera, dentro è uno quadro; miniata le margine con uno tondo abasso in bianco. Coperto lionato stampato, con quattro ciappe et cinti de velluto carmesino.

Justinus, Epitome historiarum Trogi Pompeii libri XLIV

A, 169; C, 116 ('Epithoma Justini'); V, 156; Calcagnini invent. fol. $13^{\mathrm{r}}$ ('Justinus istoricus'); Adiuto delo inventario Calcagnini, fol. $3^{v}$ ('Justini epitoma'), fol. $5^{\mathrm{r}}$ ('Justinus cum rubriche').

M 68 Franciscus Petrarca de viriis [sic] illustribus, de lettera moderna, in carta pergamena, in forma reale, scripto a colonelli. In la prima faccia è uno quadro in lo mezo de la faccie con uno $\mathrm{P}$ per prima lettera, dentro la quale è la figura del Petrarca laureato, con la margine in torno miniata con fogliagi, con uno scuto in piedi, lo qualle stato raso con le arme che ce erano; et del mezo de la faccie in su sta in bianco. Coperto russo stampato, con quattro ciappe, con li cinti de seti celestre.

Petrarch, De viris illustribus

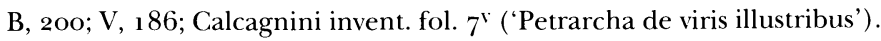

M 69 Franciscus Aretinus in heroyca Philocastri, de lettera antiqua, in quarto de foglio reale. In la prima faccie è uno quarto con una $\mathrm{C}$ per prima lettera, miniate le margine con dui tundi in bianco. Coperto russo stampato, con quattro ciappe et cinti de seti carmesino.

Francesco Griffolini, Latin translation of the Heroicus of Philostratus.

B, 217 ('Heroica Philostrati per Franciscum arretinum'); Adiuto delo inventario Calcagnini, fol. $2^{v}$ ('Heroica Philostrati').

M 1 o Flos historiarum terre orientis, in menbrana, de lettera moderna, a colonelli, in forma 
bastarda. Coperto de cammuscio verde, con una ciappa.

Heтоum, Flos historiarum terrae orientis

Calcagnini invent. fol. $7^{\mathrm{v}}$ ('Flos istoriarum terre orientis').

M 71 Historia Gottifredi regis et aliorum, de lettera [fol. $23^{v}$ ] moderna, scripto a colonelli. In la prima faccie del opera è uno $\mathrm{P}$ grande per prima lettera de azuro et russo, con parichie carte verso la fine del libro, abrusata la margine de sopra in fino a la lettera. Coperto russo stampato, con doe ciappe de ottone, con li cinti de seti russo, con frangioni et fili de oro per lo mezo.

Historia Gotifredi regis (?)

Calcagnini invent. fol. $6^{\mathrm{v}}$ ('Istoria gotifredi').

M 72 Leonardus Arethinus de primo bello punico, in menbrana, de lettera antiqua, in forma de ottavo de foglio. In la prima faccie è uno $\mathrm{O}$ dentro uno quadro per prima lettera miniata le tre margine con uno scuto abasso in bianco, studiato de russo in le margine. Coperto russo stampato, con dui ciappi et cinti de seti celestro, mangiato de sorgii a la punta del spino de la coperta.

Leonardo Bruni, De primo bello punico

A, 176 ; B, 157 ('Leonardo arretini de primo bello punico libri iij'); Adiuto delo inventario Calcagnini, fol. $2^{\mathrm{v}}$ ('Leonardus Aretinus de primo bello punico').

M1 73 De lappsu judeorum et analia imperatorum, de lettera moderna, in carta pecorina, in forma comune. In la prima faccie, dove comenza la opera, è una $\mathrm{R}$ per prima lettera in campo azuro. Coperto lionato, con quattro ciappe de ottone et dui cinti di veluto celestri con fili de oro per lo mezo.

De lapsu Judeorum et annalia imperatorum (?)

Adiuto delo inventario Calcagnini, fol. 3 ' ('De lapsu judeorum').

M 74 Leonardus Aretinus de temporibus, de lettera antiqua, in forma de ottavo de foglio reale. In la prima faccie è uno $Q$ per prima lettera miniata, in parte le tre margine con uno scuto abasso che lo tene uno angelo, le arme sono guaste. Coperto lionato stampato, con dui ciappi.

LeONARdo Bruni, De temporibus suis

A, $14^{8}$ ('Leonardi de temporibus et alia opera'); Adiuto delo inventario Calcagnini, fol. $2^{\mathrm{v}}$ ('Leonardus Aretinus de temporibus cum rubriche').

M1 75 [fol. $24^{r}$ ] Laurenzi Valle traductio herodoti, de lettera canzelaresca, in forma bastarda, in carta pergamena. In la prima faccie, dove comenza l'opera, è uno quadro con uno H dentro per prima lettera miniata, con tucta la margine in torno con uno tondo abasso de verdura, con uno scuto bianco dentro con complito. Coperto rosso stampato, con quattro ciappe con le cinti de seti celestre.

Herodotus, Historiae, in the Latin version of Lorenzo Valla

A, 19 ('Herodotus'), 183 ('Horodotus'); B, 152 ('Herodotus'); C, 61 ('Herodotus'); Calcagnini invent. fol. $4^{\mathrm{r}}$ ('Erodotus cum rubriche'); fol. $6^{\mathrm{r}}$ ('Erodotus'); Adiuto delo inventario Calcagnini, fol. $2^{\mathrm{r}}$ ('Herodotus halicarnaseus'). See also below, M1 91 .

M1 76 Victorinus, de lettera canzelaresca, in membrana in forma comune. In la prima faccie è uno quadretto con uno $\mathrm{O}$ per prima lettera miniata. Coperto rosso stampato, con quattro ciappe et cinti de seti celestre. 
MARIUS VICTORINUS (it is not possible to specify which work or works)

Adiuto delo inventario Calcagnini, fol. 2' ('Victorinus').

M 177 Vita trium poetarum, de lettera antiqua, de foglio, in menbrana. In la prima faccie è uno C per prima lettera miniata tucta una margine, et abasso uno scuto partito de la parte de sopra azuro come una hala dentro; et la altra mità, oro et verde a schiachi. Coperto rosso stampato, con quattro ciappe.

Giannozzo Manetti, Vita Dantis, Petrarcae et Boccacii (?)

B, 199 ('Vita trium poetarum'); Adiuto delo inventario Calcagnini, fol. 2' ('Vita trium poetarum').

M 78 Vita Demetrii, de lettera antiqua, in forma de ottavo de foglio reale. In la prima faccie è uno V per prima lettera miniata tucta una margine. Coperto rosso stampato, con dui ciappi. Plutarch, Vita Demetrii. Latin translation by Donato Acciaiuoli.

B, 205 ('Vita Demetrii'); Adiuto delo inventario Calcagnini, fol. 2' ('Vita Demetrii').

M1 79 Demostenis invectiva vel orationes, in carta pergamena, in forma comune. In la prima faccie de l’opera è una A per prima lettera grande. Coperto rosso stampato, con dui ciappi. [fol. $24^{v}$ ]

Demosthenes, Orationes. Probably the Latin translation of Lorenzo Valla.

A, 105 ('Orationes Demostinis et epistole Philippe grece, in papiro'), 143 ('Orationes Demosthenis per Laurentium'); B, 122 ('Invectivae Demsothenis'); Calcagnini invent. fol. $3^{\mathrm{r}}$ ('Demostenius filipice cum rubriche'), fol. $4^{\mathrm{v}}$ ('Demostenes sermones cum rubriche'). See below, M1 91 and M1 94 .

M 180 Cornelius Tacitus, in membrana, de lettera antiqua, in forma bastarda. In la prima faccie è uno quadro con uno $\mathrm{N}$ per prima lettera miniata de tre margine con uno tondo abasso in bianco. Coperto verde stampato, con quattro ciappe et cinti rossi.

TACitus, Annales

A, 55 ('Cornelius Tacitus'), 162 ('Cornelii Taciti de situ Germanie, cum aliis operibus'); B, 160 ('Cornelius Tacitus'); Calcagnini invent. fol. $12^{\mathrm{r}}$ ('Cornelij Taciti anallium libri 5 cum rubriche', 'Cornelius Tacitus'), fol. $13^{\mathrm{r}}$ ('Cornelius Tacitus'); Adiuto delo inventario Calcagnini, fol. $3^{\mathrm{v}}$ ('Cornelius Tacitus').

M1 81 Lucanus, de lettera bastarda, gliosato, vechio, in piu parte caduco. Coperto lionato con quatro ciappe.

LuCAN, Pharsalia

A, 69 ('Lucanus vetustus'), 192, 243 ('Lucanus in stampa'); B, 95; V,132; Adiuto delo inventario Calcagnini, fol. $2^{\mathrm{v}}$ ('Lucanus'), fol. $4^{\mathrm{v}}$ ('Lucanus'), fol. $7^{\mathrm{r}}$ ('Lucanus cum comm. cum rubriche').

M1 82 Lucanus, de lettera bastarda, in forma membrana, antiquo et caduco. Coperto verde stampato, con una ciappa.

LuCAn, Pharsalia

See above, M1 81 .

M1 83 Juvenalis, de lettera longobarda, in membrana, de forma bastarda, molto antiquo, in parte studiato. Coperto russo con quattro ciappi.

Juvenal, Satirae

B, 77 ('Juvenalis'); Calcagnini invent. fol. $9^{\mathrm{r}}$ ('Juvenalis'); Adiuto delo inventario Calcagnini, fol. $2^{\mathrm{v}}$ ('Juvenalis'), fol. $3^{\mathrm{r}}$ ('Juvenalis antiquus longobardus'). 
M1 84 Juvenalis, antiquo, de lettera bastarda, gliosato et quasi tucto caduco et in parte squaternato. Coperto russo stampato, con doe ciappe et cinti de seti carmesino.

Juvenal, Satirae

See above, $M_{1} 8_{3}$.

M1 85 Terentius, de lettera moderna, in carta pergamena, in forma bastarda, in parte gliosato. Et in la prima faccie, dove comenza l'opera, è uno quattro de oro con una $\mathrm{T}$ dentro per prima lettera, miniato de rosse, con una coda che tene tucta la margine; et per dentro in ogne capitulo sono quatri con le prime lettere maiuscule, impero de minie grosse et antiquaglie. Coperto russo stampato, con quattro ciappi de ottone, con li cinti de seti carmesino, con frangioni de filo de oro per lo mezo.

Terence, Comoediae sex (Andria, Eunuchus, Heautontimorumenos, Adelphi, Hecyra and Phormio)

Ferrara, Biblioteca Comunale Ariostea MS Cl. II, 171 . Fourteenth-century manuscript, in parchment, measuring $288 \times 228 \mathrm{~mm}$ and written in gothic script. It is in quite good condition but stains on some folios could have been produced by humidity (e.g. fol. $7 \mathrm{O}^{v}$ ). The binding is not original. On the first folio is the inscription: 'Terentius' (illustrated p. 229). This form of identification is documented in other manuscripts of the Aragonese library (see below, M 1 109).

A, 246,248 ; B, 87,88 ('Terentius cum comment.'); Calcagnini invent. fol. $7^{\mathrm{v}}$ ('Terentius'), fol. $9^{\mathrm{r}}$ ('Terentius', 'Terentius'), fol. $11^{*}$ ('Terrentii comedie sex cum rubriche'); Adiuto delo inventario Calcagnini, fol. 6' ('Terentius cum donato')

Other extant Terence manuscripts from the Aragonese library: Vienna, Nationalbibliothek, cod. 3o9; Ravenna, Biblioteca Classense MS 138.2.Z; El Escorial, Real Biblioteca de San Lorenzo MS S. III. 26. See De Marinis (as in n. 2), 11 , p. 157 .

M1 86 Ovidio, de lettera bastarda, in forma bastarda et in parte gliosata et antiquo, in parte rotta tarolato. Coperto lionato stampato, con doi ciappi.

OviD. It is not possible to determine which work or works.

A, 29 ('Opera Ovidii'), 190 ('Metamerphoseos'), 191 ('Ovidius de arte et aliis operibus'); B, 75 ('Ovidius'). Several works by Ovid are listed in G, nos $314^{-21}$. It is also indicated that some of these manuscripts belonged to the infantas. Calcagnini adiuto delo inventario, fol. $2^{\mathrm{r}}$ ('Ovidius de arte amandi'), fol. $4^{\mathrm{v}}$ ('Ovidii metamorphosis'), fol. $7^{\mathrm{r}}$ ('Opera Ovidii').

M $87\left[\right.$ fol. $\left.25^{r}\right]$ Virgilius, de lettera bastarda, in carta pergamena, in forma bastarda. La prima faccie miniata intorno con le arme ducale abasso. Coperto lionato con dui ciappi de ottone, con le cinti de brocato carmesino.

VERGIL. It is not possible to determine which work or works.

A, 5 ('Virgilius, impergameno'), 175 ('Virgilius'), 194 ('Virgilius'); B, 74 ('Virgilius cum glossis'); C, $5^{2}$ ('Virgilii Eneidos'); V, 129-31 (Opera omnia); G, 308 ('Otro Virgilio, encuadernado en cuero verde. De las Infantas'), 309 ('Otro Virgilio, cubierto de cuero bermejo. De las Infantas'); Calcagnini invent. fol. $9^{\mathrm{r}}$ ('Virgilius'), fol. $12^{\mathrm{v}}$ ('Virgilius in quarto'); Adiuto delo inventario Calcagnini, fol. $\mathbf{2}^{\mathrm{v}}$ ('Vergilius'), fol. $7^{\mathrm{r}}$ ('Vergelius').

M1 88 Virgilii eneidos, de lettera corsiva, in forma picola a la antiqua. In la prima faccie è uno A per prima lettera miniata con tucta una margine. Coperto de rosso stampato, con cinqui chiodi a capello per tavola, con dui ciappi et cinti de seti verde.

VERGIL, Aeneid

Adiuto delo inventario Calcagnini, fol. 4 " ('Aeneis Vergilii'). See also above, $M_{1} 87$.

M 89 Claudianus, antiquo, de lettera moderna, in membrana, in forma picola a la bastarda. In la prima faccie, dove comenza il prefactio, è uno $\mathrm{P}$ grande miniato per prima lettera. Coperto 


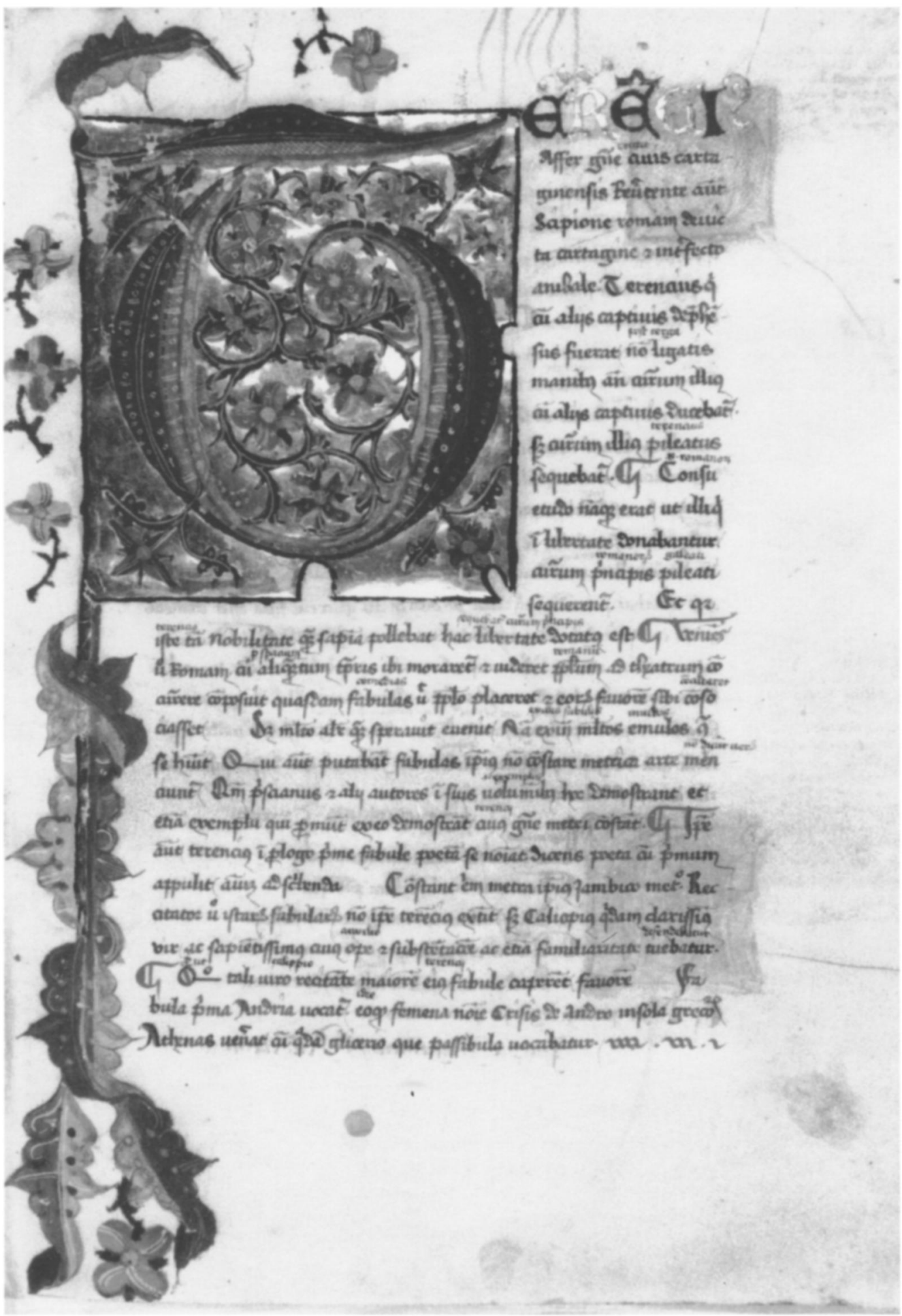

M1 85: Terence, Comoediae. Ferrara, Biblioteca Comunale Ariostea MS Cl. II, 171 , fol. $1^{\mathrm{r}}$ - COMUNE DI FERRARA, BIBLIOTECA COMUNALE ARIOSTEA 
russo stampato, de oro con quattro ciappe et cinti de seti celestre.

Claudian. It is not possible to determine which work or works.

Calcagnini invent. fol. $8^{\mathrm{r}}$ ('Claudiani opera'), fol. $9^{\mathrm{r}}$ ('Claudiani opera cum rubriche'); Adiuto delo inventario Calcagnini, fol. $3^{\mathrm{v}}$ ('Claudianus vetus').

M 190 Titi Vespesiani Stroze poete, de lettera bastarda, in forma de quarto de foglio. In la prima faccie è uno $\mathrm{C}$ per prima lettera, miniate le margine con uno scuto abasso partito in quarto de oro et de azuro con certe sbare russe de oro, con tre meze lune bianche et dui ziglii de oro per quanto de azuro con lo rastello sopra dicti ziglii. Coperto rosso stampato, con quatro chiodi per taula è ciappi.

Tito Vespasiano Strozzi, Haeroticon libri VI

Ferrara, Biblioteca Comunale Ariostea MS Cl. I, 368 (Giuseppe Antonelli, Indice dei manoscritti della civica biblioteca di Ferrara. Parte prima, Ferrara 1884 , p. 182). Fifteenth-century manuscript, in parchment, measuring $214 \times 147 \mathrm{~mm}$ and written in humanist script. As the description in $\mathrm{M}_{1}$ indicates, fol. $1^{\mathrm{r}}$ has decorated margins and a coat of arms, which, according to Antonelli, is the Strozzi stemma (illustrated p. 231). The binding is original.

Adiuto delo inventario Calcagnini, fol. 2"' ('Titi Stroze erotica').

M 91 Laurentii Valla opera, de lettera bastarda, scripta in carta pergamena, in forma bastarda, con la prima lettera miniata. Coperto lionato, con li ciappe de ottone, con li cinti de seti verde. LOREnZo VAlla, Opera

A, $5^{\circ}$ ('Helias Homeri per Laurencium'), $5^{6}$ ('Dialetica Laurencii'), 57 ('Laurencii de donatione'), 61 ('Laurencii elegantie'), 62 ('Laurencii de summo bono et aliis operibus'), 88 ('Laurencii equonomica, in papiro'), 9o ('Laurencii de libro arbitrio et traductio fabularum exopi, in papiro'), 95 ('Laurencii antidotum, in papiro'), 131 ('Laurentii varia opera'), 143 ('Orationes Demosthenis per Laurentium'), 163 ('Laurencii Valle diversa opuscula'); B, 5 ('Grammatica Laurentii Vallensis'), 6 ('Elegantiae eiusdem'), $5^{8}$ ('Valla in epistolas Poggii'), 111 ('Ilias Homeri traducta per Vallam'), 133 ('Philosophia Laurentii Vallae'); C, 132 ('Laurencii Vallensis de notulis Radensis'), 133 ('Laurencii Vallensis Thucididis'), 134 ('Dialectica Laurencii Valla'); V, 95 ('La traductione de Tucidide historico'), 96 ('Un altro libro de Tucidide'), 97 ('le allegancie'), 98 (idem), 99 ('Ilias Homeri poete in latinum sermonem'), 1 oo ('un altro libro de le epistole del Pogio de Laurenzo Valla'); Calcagnini invent. fol. $9^{\mathrm{v}}$ ('Laurentii Valla cum rubriche'), fol. $13^{\mathrm{v}}$ ('Laurentii Valle istorie cum rubriche').

Mı 92 Joannis Pontani apiratio, de lettera antiqua, in forma comune, in menbrana. In la prima faccie de l'opera è uno quatro con una E per prima [fol. $25^{v}$ ] lettera con la figura del Pontano dentro, miniate le margine, et abasso è uno scuto de argento con la aquila negra dentro, et ad ogne principio de capitulo è la maiuscula miniata et uno righo de lettere de oro. Coperto lionato stampato, con quattro ciappe et cinti de seti russo.

Giovanni Pontano, De aspiratione

Milan, Biblioteca Ambrosiana MS I. 66 sup. (?) (see R. Cipriani, Codici miniati dell'Ambrosiana: contributo a un catalogo, Milan 1968, p. 73; Inventario Ceruti dei manoscritti della Biblioteca Ambrosiana, facs. edn, Milan 1977, III, p. 696; G. Germano, Per l'edizione critica 'De aspiratione' di Giovanni Pontano, Naples 1985, p. 17). This is a fifteenth-century manuscript written in humanist script and probably of Neapolitan origin. As the first folio is missing, it is difficult to assert with complete certainty that this is the manuscript described on the list. It is possible that the first folio was removed because it contained miniatures. This is what happened, for example, to Ermolao Barbaro's De coelibatu (see above, M 147 ). The manuscript in the Ambrosiana has gold initials, and its measurements, $265 \times 182 \mathrm{~mm}$ (Cipriani, p. 73), correspond to the description in $M_{1}$. See also below, $M_{1} 109$.

A, 67 ('Aspiracio Pontanica, in pergameno'); B, ('Aspiratio Pontani'); Adiuto delo inventario Calcagnini, fol. $4^{\mathrm{r}}$ ('De aspiratione cum rubriche').

Another manuscript of De aspiratione from the Aragonese library is Paris, Bibliothèque Nationale MS latin $75^{23}$ (see De Marinis, as in n. 2, Suppl., I, pp. 80-81). 


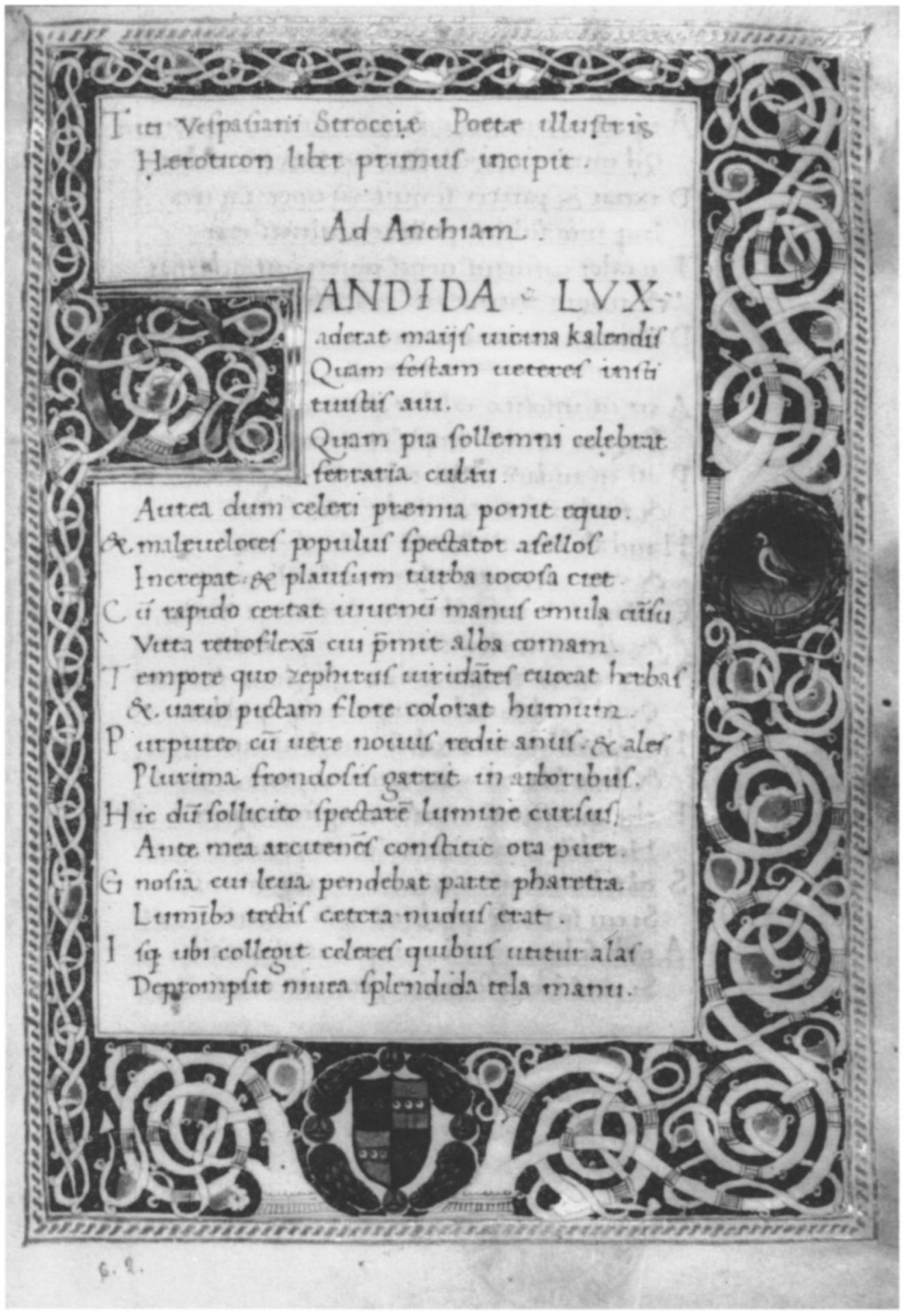

M1 9o: Tito Vespasiano Strozzi, Haeroticon libri VI. Ferrara, Biblioteca Comunale Ariostea MS Cl. I, 368 , fol. $1^{\mathrm{r}}$ ๑ COMUNE DI FERRARA, BIBLIOTECA COMUNALE ARIOSTEA 
M1 93 Plinii epistole de viris illustribus, de lettera antiqua, in forma bastarda. Al incontro de la prima faccie de l'opera è uno tundo con lettere de oro et argento sopra campo russo con la intitulatione del libro, con le arme ducale sopra dicto tundo. Et in dicta prima faccie del opera è uno quatro con una $\mathrm{C}$ miniata la margine con le arme ducale abasso. Coperto russo stampato, con quattro ciappe et cinti de seti carmesino.

Pliny The Younger, Epistolae

A, 145 ('Epistole Plinii'); B, 57 ('Epistolae Plinii'), 206 bis ('Plinius de viris illustribus'), C, 78 ('Epistole Plinii Cecilini Secundi'); Calcagnini invent. fol. $4^{v}$ ('Epistola plinii'), fol. $7^{v}$ ('Plinii epistola cum rubriche'); Adiuto delo inventario Calcagnini, fol. $2^{\mathrm{r}}$ ('Epistole Plinii'), fol. $5^{\mathrm{r}}$ ('C. Plinii Secundi epistole').

Mı 94 Laurentii Valla traductio orationis Demostenis, de lettera bastarda, in forma picola a la antiqua. In la prima faccie, dove comenza il prohemio, è una $\mathrm{O}$ per prima lettera miniata che tene tucta la margine. Coperto lionato stampato, con quattro ciappe et cinti de seti verde.

Demosthenes, Orationes. Lorenzo Valla's Latin translation

A, 105 ('Orationes Demostenis et epistole Philippi grece, in papiro'), 143 ('Orationes Demosthenis, per Laurentium'); B, 122 ('Invectivae Demosthenis'); Calcagnini invent. fol. $3^{\mathrm{r}}$ ('Demostenius filipice

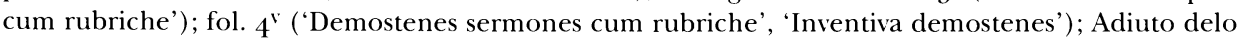
inventario Calcagnini, fol. $1^{\mathrm{v}}$ ('Demosthenis orationis cum rubriche'), fol. $2^{\mathrm{v}}$ ('Oratio Demosthenis et alia'). See also above, $M_{1} 79$ and Mi 91 .

Mi 95 Digesta vetera, in carta pergamena, scripto a colonelli, de lettera moderna, con lo comento intorno. La prima carta miniata a figure. Coperto russo con quattro ciappe de ottone.

Digestum, I-XXIV(2)

A, 263-66 ('Uno Degesto vecchio et uno codico cum due lecture, ad stampa'); Calcagnini invent. fol. $6^{\mathrm{r}}$ ('Digesta'), fol. 6' ('Digestum vetus').

M 96 Digestum novum, de lettera moderna, scripto a colonelli, con lo comento intorno. La prima faccie miniata con le arme reale in piede. In carta pergamena, in forma reale bolognese. Coperto russo stampato de oro, con quattro ciappe dorate, con le corregie de brocato carmesino russo.

Digestum, XXXIX-1

Calcagnini invent. fol. $6^{\mathrm{r}}$ ('Digestum novum').

M 97 Decretum, sine principio, de lettera moderna, a colonelli, in carta pergamena, in forma reale, che monstra assai antiqua. Et mancano alcune carte in principio et la ultima carta è in $\left[f o l .26^{r}\right]$ parte rotta è caduca. Coperto lionato, con quattro ciappe de ottone.

Decretum Gratiani

B, 239 ('Decretum'); Calcagnini invent. fol. $6^{\mathrm{r}}$ ('Decretum sine principio').

M $9_{8}$ Decretale Bonificati, de lettera moderna, scripto a colonelli, in carta montenina, in forma bastarda.

BONIFACE VIII, Liber sextus decretalium

B, 241 ('Sextus decretalium'), $25^{8}$ ('Bonifatius super Decreto'); Calcagnini invent. fol. 6' ('Sextus decretalium'), fol. $7^{\mathrm{v}}$ ('Sextus liber decretalium bonifacij').

M 199 Lo Infforzato, de lettera moderna, con lo comento, scripto a colonelli, in carta pergamena, in forma reale bolognese. La prima faccie have uno quattro de figure. Coperto lionato, con doe ciappe comune. 
Digestum infortiatum, i.e., Digest, $\mathrm{xxIV}(3)-\mathrm{xxxvIII}$

A, 261-62 ('Dui infortiati'); B, 266 ('Lectura super Infortiatum'), 271 ('Joannes Faber super Infortiato'); Calcagnini invent. fol. 6 $6^{\mathrm{r}}$ ('Isforzatum'), fol. $7^{\mathrm{r}}$ ('Isforciatum') .

M1 100 Ordo justiciarius Magni Tancredi, antiquo, de lettera corsiva miniata, a colonelli, in forma picolo. Coperto lionato stampato, con tre ciappe et cinti russi. Magnato in parte lo spino de surici.

TANCRed of Bologna, Ordo iudicarius

Adiuto delo inventario Calcagnini, fol. 2" ('Ordo justiciarius').

M1 101 Summa Hostiensis super titulis decretalium, de lettera antiqua, a colonelli, in carta pergamena, in forma reale bolognese. Coperto lionato, con quattro ciappe, con li cinti de velluto carmesino.

Henricus de Segusio, Cardinal Hostiensis, Summa super titulis decretalium

B, 245 ('Summa Hostiensis'), 254 ('Henricus super prima et secunda parte decretalium'); Calcagnini invent. fol. $6^{\mathrm{v}}$ ('Summa hostiensis supra titulum decretalis').

M1 102 Clementine, in forma reale grande, in menbrana, de lettera moderna, a colonelli, con glose. In la prima faccie è uno quatro con la figura de uno Papa in mezo e dui cardinali in piede al papa, dentro dicto quatro è uno sairo bianco con una sbarra rossa con tre gelii gialli. Coperto de cammuscio giallo. In parte de la coperta del spino magnato de surici.

Clement V, Constitutiones

B, 242 ('Clementinae'); Calcagnini invent. fol. 6' ('Clementina', 'Clementina').

M1 103 Decretales cum glosis, de lettera moderna, scripto a colonelli. In la prima faccie è uno quatretto con una $\mathrm{C}$ dentro per prima lettera, la quale prima faccie è caduca per antiquità. Coperto russo stampato, con quattro ciappe de ottone, con li cinti de seti celestre, con frangioni et fili de oro.

Gregory IX, Decretales

B, 240 ('Decretales'); Calcagnini invent. fol. 6' ('Decretales', 'Decretales').

M1 104 Speculum Gulielmi Durandi, de lettera moderna, [fol. $\left.26^{v}\right]$ scripto a colonelli, in carta pergamena, in forma grande. La prima carta è pertosata in una parte et stracciata et è senza lettera maiuscula in principio. Coperto lionato stampato, con quattro ciappe de ottone, con tre corregie de velluto celestre et una de velluto russo.

Guilelmus Durandus, Speculum iudiciale

Calcagnini invent. fol. $7^{\mathrm{r}}$ ('Speculum Guielmo Durantis').

M1 105 Innocentius super Decretalibus, scripto a colonelli, in carta pergamena, in forma reale. Coperto russo, con quattro ciappe de ottone, con le corregie de cinto de velluto carmesino.

INNOCENT III, Super decretalibus

Calcagnini invent. fol. $7^{\mathrm{r}}$ ('Inocentius').

M1 106 Rationale divinorum officiorum, ad stampa, a colonelli, con la tavola in principio in carta pecorina. Et in la prima faccie, dove comenza il prologo, è uno $Q$ per prima lettera miniato de cinabrio. Coperto de corduana lionata stampato, con quattro ciappe de ottone, con li cinti de seti carmesino, con frangioni et fili de oro per lo mezo.

Guilelmus Durandus, Rationale divinorum officiorum. Printed edition. 
B, 435 ('Rationale divinorum officiorum'); G, 204 ('Rationale divinorum officiorum Guillermi Durandi. En tablas. De las infantas'); G, 205 ('Otro libro de la misma manera. De las infantas'); Calcagnini invent. fol. $7^{\mathrm{r}}$ ('Racionale Divinorum officiorum').

M 107 Isidori musica, in menbrana, de lettera antiqua, in quarto de foglio. La prima carta è caduca e rotta per antiquità, figurato secondo la materia. Rosicato a lo spino sopra la coperta. Coperto russo stampato, con doe ciappe et cinta de seti nigro.

IsIDORE OF SEVILLE, Etymologiae, III.1 $5^{-23}$

B, 7o ('Musica Isidori'); Adiuto delo inventario Calcagnini, fol. $2^{\mathrm{v}}$ ('Musica Isidori').

M1 108 Musica Boetii, de lettera bastarda, a colonelli, in forma bastarda. Coperto russo con quattro ciappe et cinti nigri.

Boethius, De institutione musica

B, 69 ('Musica Boetii'); Adiuto delo inventario Calcagnini, fol. 2 ('Musica Boetii').

M1 109 Augustinus de civitate Dei, de lettera moderna, a colonelli, in forma comune, con la tavola in principio. Et in la prima faccie de l'opera è uno quatro con una $\mathrm{E}$ per prima lettera, miniata a tronconi. Coperto lionato, con quattro ciappe et cinti de seti russo. [fol. $27^{r}$ ]

St Augustine, De civitate Dei, in Italian.

Ferrara, Biblioteca Comunale Ariostea MS Cl. II, 3. This is a fifteenth-century manuscript in parchment, measuring $255 \times 180 \mathrm{~mm}$. The first nine folios, written in a cursive humanist script, contain the index of the work. The ' $\mathrm{E}$ ' described in $\mathrm{M}_{1}$ is on fol. $1 \mathrm{O}^{\mathrm{r}}$ (illustrated p. 235). The binding is the original. On the inside of the back cover is written 'Vulgari theologi no xviiii', which is a frequent form of identification in books from the royal Aragonese library. A clear indication that this manuscript comes from the Dominican convent of Ferrara is found on the first folio: 'est conventus Sancti Dominci de Ferrarie'. The manuscript is in fairly good condition, but some folios have been cut.

Calcagnini invent. fol. $7^{\mathrm{v}}$ ('Augustinus de civitate dei vulgare', 'Augustinus de civitate dei'), fol. $12^{\mathrm{r}}$ ('Augustini de civitate Dei'). See also above, M1 14.

M1 110 Fiori de virtù, de lettera moderna grossa, in carta pergamena, in forma picola, antiquo assay. Coperto morato stampato, con doe ciappe de ottone, con corregie de seti morato pinno, con frangioni intorno et tre fili de oro per lo mezo.

Fiori di virtù

Adiuto delo inventario Calcagnini, fol. $2^{\mathrm{r}}$ ('De floribus virtutum').

M1 111 De Regimine principum, in menbrana, de lettera moderna, a colonelli, in forma bastarda. Coperto russo stampato, con quattro ciappe.

GiLes of RoMe, De regimine principum

A, 187 ('Egidius de regimine regum'); B, 306 ('De regimine principum'), 310 ('Aegidius de regimine principum'); Calcagnini invent. fol. $7^{`}$ ('De regimine principum').

M1 112 Li quattro Evangellista, de lettera moderna, in menbrana, in forma picola. In la prima faccie è uno quattro con la figura de Sancto Luca scribente, miniate le margine con uno scuto abasso con arme. Coperto lionato stampato, con doe ciappe et cinti de seti carmesino.

GOSPELS

Adiuto delo inventario Calcagnini, fol. $4^{\mathrm{v}}$ ('i quattro evangelisti'). See also above, M 6.

M1 113 Speculum fidei, in papiro, ad penna, de lettera corsiva. Coperto russo stampato, con quattro ciappe et cinti russi. 


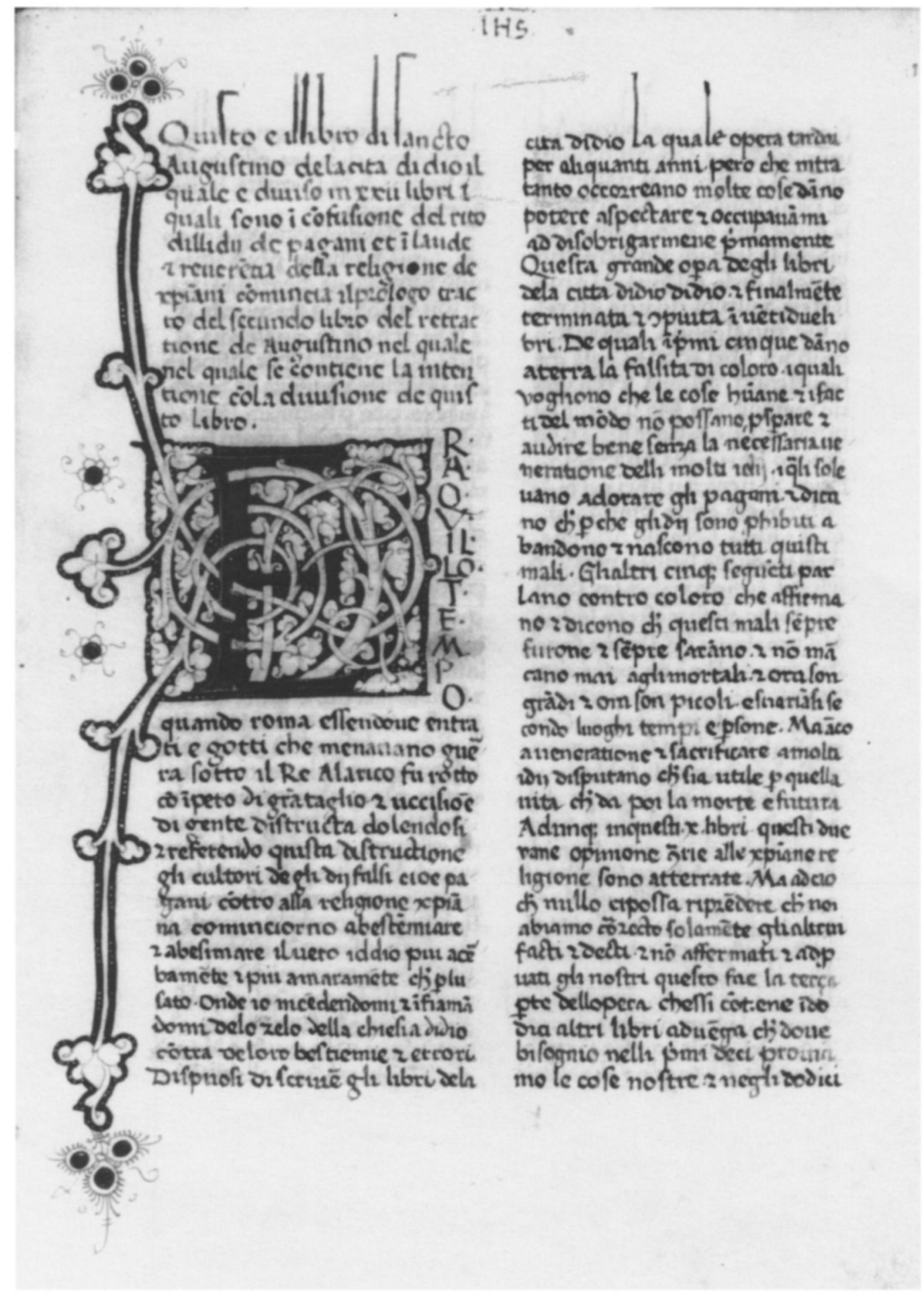

M1 1 og: St Augustine, De civitate Dei (Italian). Ferrara, Biblioteca Comunale Ariostea MS Cl. II, 3, fol. $10^{\mathrm{r}}$ 
Robert of Cricklade, Speculum fidei

Calcagnini invent. fol. 6' ('Speculum fidei et sermoni di fra Roberto'). See above, M1 31 .

M1 114 Soliloquii de Sancto Augustino, de lettera moderna, in ottavo de foglio, con la tavola in principio, senza minie. Coperto russo stampato, senza ciappe.

St Augustine, Soliloquia

B, $3^{61}$ ('De confesionibus et diversa alia eius [Augustini] opuscula'); Adiuto delo inventario Calcagnini, fol. 2" ('Soliloquii Sancti Augustini').

M 1115 Valerius Maximus, a colonelli, in membrana, in forma reale, senza coperta.

Valerius Maximus, Factorum ac dictorum memorabilium libri IX

See above, $M_{1} 5^{6 .}$

M1 116 Le cente novelle de Joan Boccatio, de lettera antiqua, in forma reale, con la tavola in principio. Et in la prima faccie, dove comenza l'opera, è uno quattro con una H per prima lettera, dentro de la quale è la figura del Boccatio scribente, miniate le margine con diversi tundi et figure dentro, con uno scuto abasso con lo campo [fol. $\left.27^{v}\right]$ de oro miniato con una sbara de russo in mezo; et in ogne capitulo è una lettera maiuscula miniata. Coperto russo stampato, con quattro ciappe et con cinque chiodi et piastre de ottone per le tavole d'ogni bande, con li cinti de seti carmesino.

Giovanni Boccaccio, Decameron

V, 292; Calcagnini invent. fol. $11^{\mathrm{r}}$ ('Cento novelle in folio reale di coperto'); Adiuto delo inventario Calcagnini, fol. $6^{\mathrm{r}}$ ('Le cento novelle').

M 1117 Dante in versi, de lettera moderna, a colonelli, glosato intorno, historiato antiquo che in parte è caduco. Et in la prima faccie, dove comenza la comedia, è uno quatro con una M per prima lettera miniata con le arme ducale abasso. Coperto lionato stampato, con quattro ciappe, con li cinti de seti carmesino.

Dante Alighieri, Commedia

New York, Pierpont Morgan Library MS M.676 (illustrated p. 237); see Catalogue of Very Important Illuminated and Other Manuscripts the Property of the Lord Mostyn ... which will be sold by auction by messrs Sotheby, Wilkinson $\mathcal{E}$ Hodge, London 1920, no. 28, pp. 8-9; The Pierpont Morgan Library Exhibition of Illuminated Manuscripts Held at the New York Public Librany, New York 1934, p. 44 n. 91, pl. 73; De Marinis (as in n. 2), II, pp. 61-62, 322, pls 4-7; M. Harrsen and G. K. Bovce, Italian Manuscripts in the Pierpont Morgan Library, New York 1953, p. 26, pls $3^{8}, 39$; P. Brieger, M. Meiss and C. S. Singleton, Illuminated Manuscripts of the Divine Comedy, Princeton 1969 , I, pp. 295-300; M. Roddewig, Dante Alighieri, Die göttliche Komödie: Vergleichende Bestandsaufnahme der 'Commedia'-Handschriften, Stuttgart 1984, pp. $215^{-16}$. Fourteenth-century manuscript, in parchment, measuring $35^{\circ} \times 260 \mathrm{~mm}$ and illustrated with numerous miniatures. The text, in gothic script, has marginal glosses in Italian by an anonymous annotator. A note indicates that this manuscript was given by Dr Antonio Testa of Ferrara to Girolamo Baruffaldi $\left(1675^{-1755}\right.$ ) on 7 January 1702 (De Marinis, as in n. 2, II, p. 61). It was later owned by Thomas Hobart. In the nineteenth century it was bought by Llewellyn, 3rd Baron Mostyn (1856-1929), and in March 1923 acquired by J. P. Morgan.

B, 103 ('Dantes'); V, 286; Adiuto delo inventario Calcagnini, fol. 4' ('Danthe').

Another extant manuscript of the Commedia from the Aragonese library is London, British Library MS Yates Thompson $3^{6}$ (see De Marinis, as in n. 2, II, pp. 62-63; Cherchi and De Robertis, as in n. 5 , p. 270 ).

M 1118 Bernardi Licini in rima, de lettera corsiva, in carta pergamena, in forma picola. In la prima faccie comenza lo exordio, con uno sonetto che comenza: 'Sforzame ora mai'. Coperto de corduana negra stampato, con doe ciappe de ottone. 


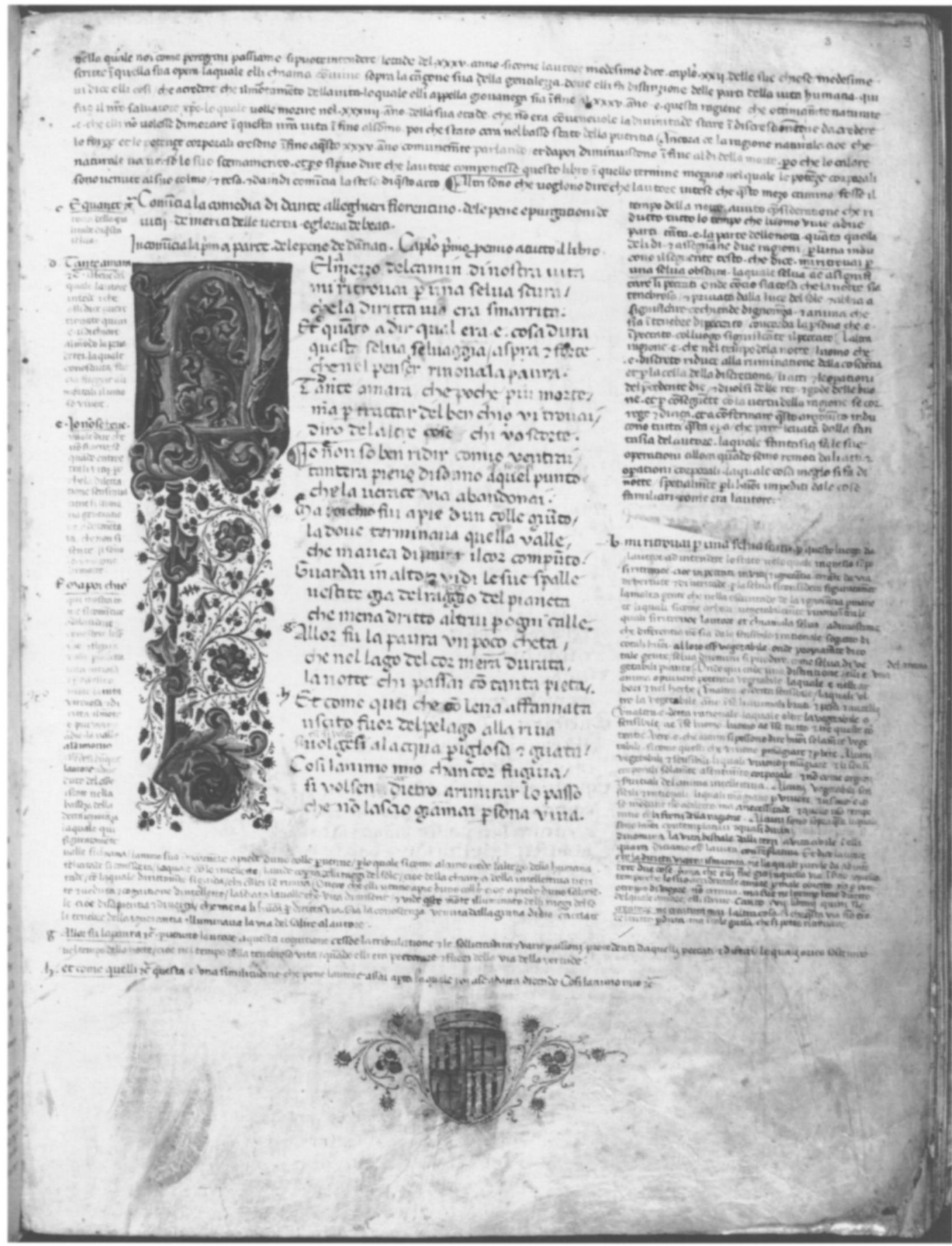

M1 1 17: Dante Alighieri, Divina Commedia. New York, Pierpont Morgan Library MS M.676, fol. $3^{\text {r }}$ (C) THE PIERPONT MORGAN LIBRARY. PHOTOGRAPHY: JOSEPH ZEHAVI 
Bernardo Ilicino (i.e., Bernardo Lapini), Poems (I believe this must be the work referred to, since no reference is made to Petrarch's Trionfi)

Adiuto delo inventario Calcagnini, fol. 2' ('Bernardus Illicinus').

M1 119 Le epistole de Ovidio a stampa. Coperto russo, con due ciappe.

Ovid, Heroides. Printed edition.

Calcagnini invent. fol. $11^{\mathrm{v}}$ ('Epistola Ovidii'); Adiuto delo inventario Calcagnini, fol. $4^{\mathrm{v}}$ ('Ovidii elegie').

For references to works of Ovid in the Aragonese library see above, $M_{1} 86$.

M1 120 Libro spagnolo, in papiro, a penna. Coperto nigro, con cinque chiodi per tavola.

It is impossible to identify which Spanish work is referred to here.

M1 121 De sanitate in Gallico, de lettera moderna, in carta pergamena, de foglio comune. La prima lettera de l'opera è uno $\mathrm{P}$ miniato. Coperto de corduana rossa stampato, con quattro ciappe de ottone.

De sanitate (?), in French

Calcagnini invent. fol. $5^{\mathrm{v}}$ ('Galenus de sanitate tuenda'); Adiuto delo inventario Calcagnini, fol. $2^{\mathrm{v}}$ ('De sanitate conservanda').

M1 122 Monarchia de Dante, de lettera canzelaresca, in carta pergamena, in forma piccola. In la prima faccie è uno tundo miniato, con lettere de oro et azuro dentro. Et la prima faccie de l'opera è miniata in- [ fol. $28^{r}$ ] torno con uno tundo abasso de verdura con lo campo bianco. Coperto paunazo stampato, con quattro ciappe de ottone lavorate, con li cinti de seti verde.

Dante Alighieri, Monarchia

M1 123 Tractatus de patientia, de lettera moderna, in forma picola, con la tavola in principio. Et in la prima faccie de l'opera è uno A rosso per prima lettera. Coperto lionato stampato, con quattro ciappe et cinti de seti carmesino, con frangioni.

Lucianus (?), Tractatus de patientia

Calcagnini invent. fol. $7^{\mathrm{v}}$ ('Lucianus tractatus de pacientia').

M 124 Psalmi et oratione, scripte in lengua et in lettera francese, de carta de papiro, ad quarto de foglio. La prima lettera è una A miniata. Coperto russo stampato, con due ciappe.

PSALMS AND PRAYERS

See above, M1 2.

M1 125 Contempto del mundo de don Pietro, in papiro, a penna, in castigliano. Coperto uerde.

Condestable Don Pedro of Portugal, Coplas del menosprecio e contempto de las cosas fermosas del mundo Adiuto delo inventario Calcagnini, fol. $3^{\mathrm{v}}$ ('Contemto del mondo').

M1 126 Li diece comandamenti de la legie, in lingua francese, de lettera moderna, a colonelli in forma bastarda, historiato, opera antiqua. In la prima faccie è uno quattro con dui appartamenti, miniate le margine intorno è figure. Coperto russo stampato, con quattro ciappi.

The Ten Commandments, in French

Li sopra scripti centi vinti sei volumi de libri sonno noctati a lo inventario grande fate in Isca. ${ }^{67}$

67. MS: in inisca. 
M 127 Dicta clarorum virorum, in carta menbrana, in octavo de foglio, scripto a mano, che tene per prima lettera una A maiuscula con una margine miniata quanto è lo longo de la scriptura. Coperto de coyro lionato chiaro, [fol. $28^{\circ}$ ] stampato de oro e azuro, con dui ciappi de rame, con cinti de seti ${ }^{68}$ verde.

Dicta clarorum virorum

B, 212 ('Dicta clarorum virorum'); Calcagnini invent., fol. $3^{\mathrm{r}}$ ('Preclara ditta filosoforum').

M1 128 Jacobus Campolus de regia dignitate, in carta menbrana, in quarto de foglio, de lettera canzelaresca, con tre margine miniate, in una de li quali è una figura che tene uno scutello con le arme de Aragona con le arme reale abasso, con sei tondetti de oro allo intorno. Coperto de coyro lionato chiaro stampato, con dui chiodendi de rame con cinti de seta celestre, con certi fili d'oro seminati do sopra.

Jacobus Campolus, De regia dignitate (?).

B, 213 ('De regia dignitate'); Adiuto delo inventario Calcagnini, fol. 2 ('Jacobus Campolus').

M1 129 Livius de bello macedonio, in carta menbrana, de foglio reale bolognese. In principio del quale è uno quatro con una M maiu[s]cola per prima lettera, con uno corto ucello alli fronte de dicta emme in la margine de sopra con la margine de sotto miniata a ucelli, è uno scuto in mezo con lo canpo de oro con una mitria de sopra. Coperto di coyro russo stampato, con quattro ciappe de rame, con cinti celestre, con frangioni.

Livy, Ab urbe condita, XXI-XLV

A, 123 ('Livius, in stampa, de bello macedonico'); C, 39 ('Titi Livii de bello Macedonico primo'), 40 ('Titi Livii de bello macedonico secundo'); Calcagnini invent. fol. $8^{\mathrm{r}}$ ('Livius de bello macedonico'). See also above, M1 53 .

M1 130 Marcilii in victa Caroli magni, scripto a penna, in carta pergamena, quale non se troveno in lo inventario.

Marsilius, Vita Caroli Magni (?)

M1 131 Uno libro in lingua spagnola, in foglio reale bastardo. Coperto rosso, in la fronte del libro è scripto: La quarta partita, quale non se troua in lo inuentario.

Alfonso X, Cuarta Partida

M1 132 Uno libro scripto a penna, in volume comune, quale dice: De summa trinitate, quale non se trova in lo inventario.

De summa trinitate

Però quando li sopra dicti tri libri quale non se sonno trovati al presente quando se trovarano se averano a far bono al dicto Federico a li soi conti. Li predicti tre libri, cio è Dicta clarorum virorum, Jacobus Campulus et Livius de bello macedonio, sono noctati al conto de li libri quali erano in poter del condan Joanne Antonio de Costanze, noctati a carte $3^{6}$ et 37 et $3^{8}$.

Tucti li predicti centi trenta dui volumi de libri son stati venducti al predicto micer Celio Calcagnino per lo predicto precio de lire cento cinquanta, de acordo, per causa che la maior parte de dicti libri erano guasti per causa se bagnarno quando forno portati da Ischa in Marcerglia et de Marciglia in Ferrara et ancora a multi erano cadutte le lettere per la lore antiquità. De le quale lire cento cinquanta lo dicto Federico del Tuffo se ne farà introito et ne darà conto. Et per che de tale ordine et venditione el dicto Federico non è mandato alcuno de Vostra Maesta piaza ad quella signarli lo 
presente memoriale, lo quale li sia sufficiente cautella a lo rendere de soi conti.

$\mathrm{L} 15^{\circ}$

piaceme

Expedicto in Ferrara a di iiij de juglii 1523.

Rinaldo Ottavantis.

\section{Inventory $\mathrm{M}_{2}$}

Madrid, Archivo Histórico Nacional, Sección de Códices MS ${ }_{5}^{62} \mathrm{~B}$, fol. $3^{6^{\mathrm{v}}}$

\section{Sua Reale Maestà}

Per ordine de Vostra Maestà, Federico del Tufo, guardaroba magiore de quella, ha donato li sotto scripti libri ali infra scripti persone, che Sua Maestà ne li ha facto gratia:

M2 1 Primo, allo Illustre S. Francesco Cantelmo lo libro de cacia, scripto in lettera francese ha mano, nominato Febus. Coperto de coiro lionato.

Gaston Phebus, Livre de la chasse

V, 253 ('Febus de Conte de Phois amaestramenti de la caza de omne natura de animale et lomodo et ordine de cazare et allivare li cani')

M2 2 Al dicto S. Francesco lo libro nominato li quatro arte de guerra, scripto a mano, in lettera francese, in carta pergamena. Coperto de seti lionato vechio.

Quatro arte de guerra

M2 3 Al dicto, lo libro nominato lo brasone de arme. Coperto de coiro ruso.

Brasone de arme

This must be the work mentioned in $\mathrm{D}, 205$ ('Lo blasone de armarie, composto per la muortale memoria del re Federico').

M2 4 Al dicto, lo libro nominato le prove de galiam, in francese. Coperto de coiro verde.

Prove de Galiam, in French

M2 5 A Colla di Gervasi, vostro guardaroba, per tenerlo per la Maesta Vostra, lo dialogo de Sancto Jeronimo. Coperto de coiro lionato stampato.

Pseudo-Jerome, Dialogus de origine animarum, or St Jerome, Dialogi contra Pelagianos (?)

M2 6 Al dicto Colla lo libro de Sidrac judeo, che fa risposta al re, con le arme del principe de Tarant. Coperto vechio.

Sydrac le philosophe, le livre de la fontaine de toutes sciences

M2 7 Al monesterio de Sancto Giorgio de Ferrara lo libro epistolarum, ordinato secundo consuetudine sisterniensis. Coperto lionato vechio.

Liber epistolarum (?)

M2 8 A Joan Michael, francese, cantor del signore Duca de Ferrara lo canzonero in francese in carta pergamena. Coperto de coiro ruso.

An anthology of poetry, in French 
M2 9 A mistro Paulo Marmo, medico, che de suo officio serve la casa senza premio, lo libro nominato l'Avicena, de foglio riale, de carta pergamena, scripto a penna e miniato in alcuno locho in tavoleto, et coperto de coiro.

Avicenna, Canon

B, 320 ('Avicenna').

M2 10 A Donno Loyso de Riciis, capelano de la Maestà Vostra, lo libro nominato Valerio Maximo a stampa. Coperto de coiro lionato.

VALerius MaXimus, Factorum ac dictorum memorabilium libri IX

$\mathrm{V}, 223$. See also above, $M_{1} 5^{6}$.

Li qualli predicti libri son quelli consigno Francisco da Penna che li portò da Marceglia et per che de tal donatione lo predicto Federico non ne ha mandato alcuno piacerà a la Maestà Vostra signarli lo presente memoriale che li sia sufficiente cautella al render de soi conti. Piaceme.

Expedito in Ferrara, ad xxi de Austo 1523.

Rinaldo Ottavantis

\section{Index of Names and Works}

Albert the Great

De animalibus M1 44

Alexander de Sancto Helpidio

Super Johannem . . . . . . . . . . . . . . . . . M M1 22

Alfonso X

Cuarta Partida ................. M1 131

Ambrose, St

De excessu fratris ................... $\mathrm{M}_{1} 8$

Annalia imperatorum .................. M1 73

Anthology of poetry, in French $\ldots \ldots \ldots \ldots$ M2 8

Antonio of Bitonto

Speculum animae ................. M1 30

Appian

De bellis civilibus .................. M1 66

Apuleius

De asino aureo ......................... 145

Aristotle

De animalibus ..................... M1 33

Physica........................

Augustine, St

De civitate Dei ............... M1 14, M1 109

De sermone Domini in monte . . . . . . . . . . . M 117

Retractationes .................. $\mathrm{M}_{1} 16$

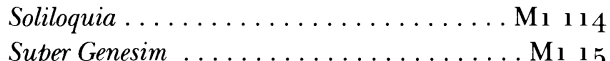

Avicenna ..................... M2 9

Balbi, John of

Catholicon .........................

Barbaro, Ermolao

De coelibatu .................. M1 47

Benedictiones filiorum Jacob . . . . . . . . . . M $\mathrm{M}_{123}$

Bible

Actus apostolorum ................ $\mathrm{M}_{15}$

Book of Revelation ................... 15

Gospels ............... M1 6, M1 112

Ten Commandments (in French) ...... M1 126

Boccaccio, Giovanni

Decameron ...................... M1 116

Boethius

De musica ................... M1 108

Boniface VIII

Liber sextus decretalium ............ Mı 98

Brasone de arme .......................

Bruni, Leonardo

De primo bello punico ................ 172

De temporibus suis ................ M1 74 
Campolus, Jacobus

De regia dignitate (?)

M1 128

Cicero

De finibus ..................... $13{ }^{6}$

Claudian $\ldots \ldots \ldots \ldots \ldots \ldots \ldots \ldots \ldots \ldots \ldots \ldots \ldots$

Clement V

Constitutiones

. M1 102

Dante Alighieri

Commedia ..................... M1 117

Monarchia ................... M 122

De lapsu Judeorum ................... M1 73

De sanitate (in French) .............. M 121

Decretum Gratiani ................... M 197

Demosthenes (transl. Valla)

Orationes M 79, M 94

Dicta clarorum virorum

Mi 127

Digest M $195-96, M_{1} 99$

Dionysius Periegetes

Cosmographia seu de situ orbis M1 62

Durandus, Guilelmus

Rationale divinorum officiorum ......... M 106 Speculum ..................... M1 104

Eutropius

Breviarium ab urbe condita Mi 64

Fiori di virtù M1 110

Flores quattuor doctorum $\ldots \ldots \ldots \ldots \ldots \ldots \mathrm{M}_{1} 21$

Gilles of Rome

Hexaemeron .................... M1 24

De regimine principum .............. M 1

Gregory IX

Decretales Mi 103

Gregory the Great, St

Dialogi ..................... M1 12-13

Epistolae........................ $\mathrm{M}_{1} 11$

Griffolini, Francesco

Latin transl. of Philostratus, Heroicus . . . . M 69

Hetoum

Flos historiarum terrae Orientis ......... M 170
Henricus de Segusio Summa super titulis Decretalium ......... M1 101

Herodotus (transl. Valla) Historiae .................... M1 75

Hierocles of Alexandria

Commentarius in aurea Pythagoreorum

carmina ...................... $1 \mathbf{l}_{4} 6$

Historia Gotifredi regis (?) ................

Hugh of Saint Victor

De bestiis et aliis rebus, book I (?) $\ldots \ldots \ldots \mathrm{M}_{1} 4^{8}$

Innocent III

Super decretalibus .................. M1 105

Isidore of Seville, $\mathrm{St}$

De vita Christi .................. M1 25

Etymologiae .............. M1 26, M1 107

Jerome, St

Dialogi contra Pelagianos (?) . . . . . . .... M2 5

Epistolae........................ M1 7-9

Super Oseam ................... M1 10

Ps-Jerome

Dialogus de origine animarum (?) . . . . . . M2 5

Josephus, Flavius

Antiquitates Judaicae . . . . . . . . . . . . . . M 163

John of Salisbury

Policraticus $\ldots \ldots \ldots \ldots \ldots \ldots \ldots \mathrm{M}_{1} 4^{2}$

Justinus

Epithoma Trogi Pompeii .............. M 67

Juvenal

Satirae ..................... $\mathrm{M}_{1} 8_{3}-8_{4}$

Lapini, Bernardo, Poems ............. M1 118

Liber epistolarum $\ldots \ldots \ldots \ldots \ldots \ldots \ldots \ldots \mathrm{M}_{2} 7$

Libro spagnolo (‡) .................... M1 120

Livy

Ab urbe condita ............ M $153-54, M_{1} 129$

Lucan

Pharsalia .................... M1 81-82

Lucianus (?)

Tractatus de patientia ............. M1 123

/continued 
Macrobius

Commentarium in Somnium

Scipionis ................. $\mathrm{M}_{15}, \mathrm{M}_{1} 4^{1}$

Manetti, Giannozzo

Vita Dantis, Petrarcae et Boccacii (?) ....... M 77

Marsilius

Vita Caroli Magni (?) ............... M1 130

Mauritius Hibernicus

Summa distinctionum.............. M 155

Missal ..........................

Ovid

? $\ldots \ldots \ldots \ldots \ldots \ldots \ldots \ldots \ldots \ldots \ldots \ldots \ldots \ldots$

Heroides ..................... M1 119

Pedro of Portugal, Condestable

Contempto del mundo ............... M 1125

Peter Lombard

Sententiae ................... M1 29

Petrarch

De viris illustribus . ............. M 68

Phebus, Gaston

De la chasse ........................ $2_{2} 1$

Philo

Sermones

Plato

Gorgias ...................... M 34

Pliny the Younger

Epistolae.

M1 93

Plutarch

Apophthegmata .................. M 49

Vita Demetri (transl. D. Acciaiuoli) $\ldots \ldots \mathrm{M}_{1} 78$

Pontano, Giovanni

De aspiratione .................. M 192

Pseudo-Heggesipus

De bello Judaico . . . . . . . . . . . . . . M $\mathrm{M}_{1} 6_{5}$

Pseudo-Isidore

De vita Christi

M 25

Prove de Galiam M2 4

Psalterium M1 2-3, M1 124

Quatro arte de guerra M2 2
Quintus Curtius

Historia Alexandri .............. ${ }_{1} 59^{-61}$

Robert of Cricklade

Speculum fidei

Mi 31, M1 113

Sallust $\ldots \ldots \ldots \ldots \ldots \ldots \ldots \ldots M_{1} 5^{8}$

Seneca

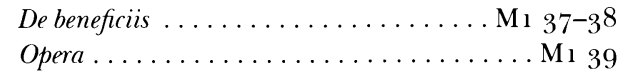

Strozzi, Tito Vespasiano

Haeroticon libri VI ................. M 190

Summa Trinitate .................... M1 132

Sydrac le philosophe ...................... M2 6

Tacitus

Annales ..................... M180

Tancred of Bologna

Ordo iudicarius ............... M1 100

Terence

Comoediae ...................... M $18_{5}$

Thomas Aquinas

Summa theologiae $I^{a} \ldots \ldots \ldots \ldots \ldots \ldots \ldots \mathrm{M}_{1} 20$

Super Matthaeum ................... M1 19

Valerius Maximus

Dicta et facta... ...... M $156-57, \mathrm{M}_{1}{ }_{11} 15, \mathrm{M}_{2} 10$

Valla, Lorenzo

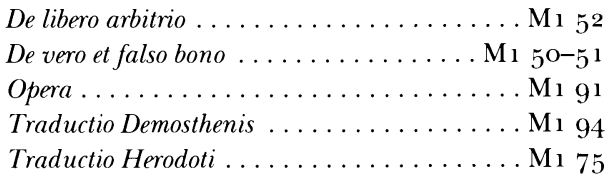

Victorinus, Marius

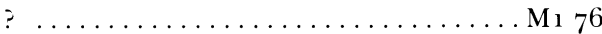

Vergil

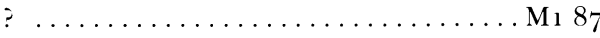

Aeneid .......................... 188

Vitae patrum $\ldots \ldots \ldots \ldots \ldots \ldots \ldots \ldots M_{1} 3^{2}$

Voragine, Jacobus de

Legenda sanctorum $\ldots \ldots \ldots \ldots \ldots \mathrm{M}_{1} 27-28$ 